\title{
Upper and uppermost Famennian (Devonian) brachiopods from north-western France (Avesnois) and southern Belgium
}

\author{
Bernard MOTTEQUIN ${ }^{* *} \&$ Denise BRICE ${ }^{2}$
}

${ }^{1}$ OD Earth and Life History, Institut royal des Sciences naturelles de Belgique, rue Vautier 29, B 1000 Brussels, Belgium; bmottequin@ naturalsciences.be.

${ }^{2}$ Université Catholique de Lille, Groupe ISA, Boulevard Vauban 48, F59046 Lille Cedex, France; Denise.Brice@isa-lille.fr.

* corresponding author

\begin{abstract}
Uppermost Famennian (Strunian) brachiopods are relatively frequent in the mixed carbonate-siliciclastic succession of north-western France (Avesnois) and southern Belgium, but they remain relatively poorly known, partly due to their generally deficient preservation. In an effort to revise the material described by Dehée in the first half of the $20^{\text {th }}$ century, which were mostly recovered from the uppermost Famennian Etrœungt Formation in the Avesnois but also most probably within the underlying Epinette Formation (upper Famennian), and to assess the brachiopod diversity prior to the Hangenberg Crisis in this area, attention was mainly focused on productides (chonetidines), rhynchonellides, athyridides, spiriferides, and spiriferinides. The type specimens of Sphenospira julii (Dehée, 1929) and Prospira struniana (Gosselet, 1879) as well as other significant specimens of Centrorhynchus letiensis (Gosselet, 1879) are re-illustrated. A new spiriferide species is recognized within the Etrœungt Formation, namely Prospira pseudostruniana sp. nov. Brachiopods from contemporaneous lithostratigraphic units occurring in Belgium are also discussed.
\end{abstract}

KEYWORDS: Upper Devonian, brachiopods, Belgium, France, Hangenberg Crisis

\section{Introduction}

As noted by several authors (e.g. Gosselet, 1857; Cooper, 1954; Conil et al., 1986; Simakov, 1990; Mottequin et al., 2014), radiations were recorded among several brachiopod orders during the uppermost Famennian (Upper Devonian). Numerous productide, spiriferide, spiriferinide and rhynchonellide genera first appeared during this interval and are characterized by morphological features heralding the Mississippian brachiopod faunas.

Brice et al. (2013) recently stressed that the brachiopod data related to the uppermost Famennian of the Avesnois (north-western France) (Fig. 1), which is the historical type area of the Strunian (Streel et al., 2006), strongly need to be updated in order to detail the consequences of the Hangenberg Crisis (Kaiser et al., 2011, 2015). In this area, the last comprehensive study on uppermost Famennian brachiopods dates back to Dehée (1929). His study, based on Gosselet, Delépine, Carpentier and Dehée's material, is poorly stratigraphically constrained and some elements of the fauna described by Dehée (1929), such as the atrypides, were not obtained from the uppermost Famennian (Copper, 1986). The brachiopods were subsequently and partly revised by Vandercammen (1956), Legrand-Blain (1991), Brice (1997), Nicollin $(2004,2008)$ and Brice et al. (2013). The situation is more critical in southern Belgium where the mixed carbonatesiliciclastic Strunian facies are relatively similar to those occurring in the Avesnois. In Belgium, the vast majority of the uppermost Famennian brachiopods is only known by lists of species (Demanet, 1958; Conil et al., 1986); a small part of them were described and illustrated (Sartenaer \& Plodowski, 1975; Legrand-Blain, 1991). It is important to note that the material, both in north-western France and southern Belgium, is usually poorly preserved. That may explain the lack of interest in these brachiopod faunas since the publication of Dehée's (1929) monograph.

The aims of this paper are (1) to continue the revision of the uppermost Famennian brachiopods from the Avesnois (Etrœungt Formation) as announced in Brice et al. (2013), (2) to precise their range and (3) to comment the brachiopod faunas from the contemporaneous succession of southern Belgium.

The investigated material is curated at the Musée d'Histoire naturelle de Lille (prefixed MGL, formerly Musée Géologique de Lille), the Faculté Libre des Sciences de Lille (prefixed GFCL, Géologie Faculté Catholique de Lille), the Institut royal des Sciences naturelles de Belgique (prefixed IRScNB) and the Université de Liège (prefixed ULg).

\section{Geological and stratigraphical setting}

\subsection{North-western France (Avesnois)}

The studied material from north-western France comes from the Avesnois (Fig. 1) and was collected between 1970 and 2013 by the members of the Faculté Libre des Sciences et Technologies de Lille; it completes the material investigated by Dehée (1929; see below). It was mainly obtained from the uppermost Famennian Etrœungt Formation, which corresponds to the 'Strunien calcaire' sensu Conil et al. (1964), but material from the underlying and overlying lithostratigraphic units, namely the Epinette (upper Famennian) and Avesnelles (uppermost Famennian-Tournaisian) formations, is also discussed (Fig. 2). The Epinette Formation (Conil \& Lys, 1968, 1970) (thickness: c. $116 \mathrm{~m}$ in the Avesnelles railway section; see below) is essentially shaly with beds of limestone and nodular limestone. It includes rugose corals and the first stromatoporoids known in the area since their demise at the end of the Frasnian (Conil \& Lys, 1970; Poty, 1999). The Etrœungt Formation attains c. $35 \mathrm{~m}$ in the Avesnelles railway section; it consists of limestones and siliciclastics including numerous levels rich in stromatoporoids (Le Maitre, 1932; Mistiaen, 1997) and was recently discussed by Mistiaen et al. (2013). The Avesnelles Formation (thickness: c. $15 \mathrm{~m}$ ) consists of dark, thin-bedded limestones devoid of corals and stromatoporoids resting abruptly on the Etrœungt Formation (Conil \& Lys, 1970). It was considered by Conil et al. (1986) as a lateral equivalent of the mostly Tournaisian-aged Hastière Formation that is well-known in southern Belgium. Hance et al. (2001) correlated the Avesnelles Formation with the two first members $(\alpha$ and $\beta$ ) of the Hastière Formation and thus, according to E. Poty (pers. com., October 2015), only its base (the equivalent of the bed 159 of the Hastière Formation in the Anseremme section (see Poty et al., 2014)), could be correlated with the Upper praesulcata Zone. Although Poty et al. (2006) have assigned the whole Avesnelles Formation to the Upper praesulcata Zone and thus considered it as entirely uppermost Famennian and not Tournaisian in age, we have followed the first opinion here. Nevertheless, the guide species of the standard conodont zonation have never been obtained so far in north-western France and southern Belgium due to unfavourable facies and it is thus not possible to trace the Devonian-Carboniferous boundary on the basis of the first appearance of Siphonodella sulcata, but according to E. Poty (pers. com., October 2015), the Hastière Formation clearly postdates the Hangenberg Event. The Hangenberg Event should be located at the boundary between the Etroungt Formation and the black-coloured limestones of the Avesnelles Formation according to Hubert et al. (2013). 


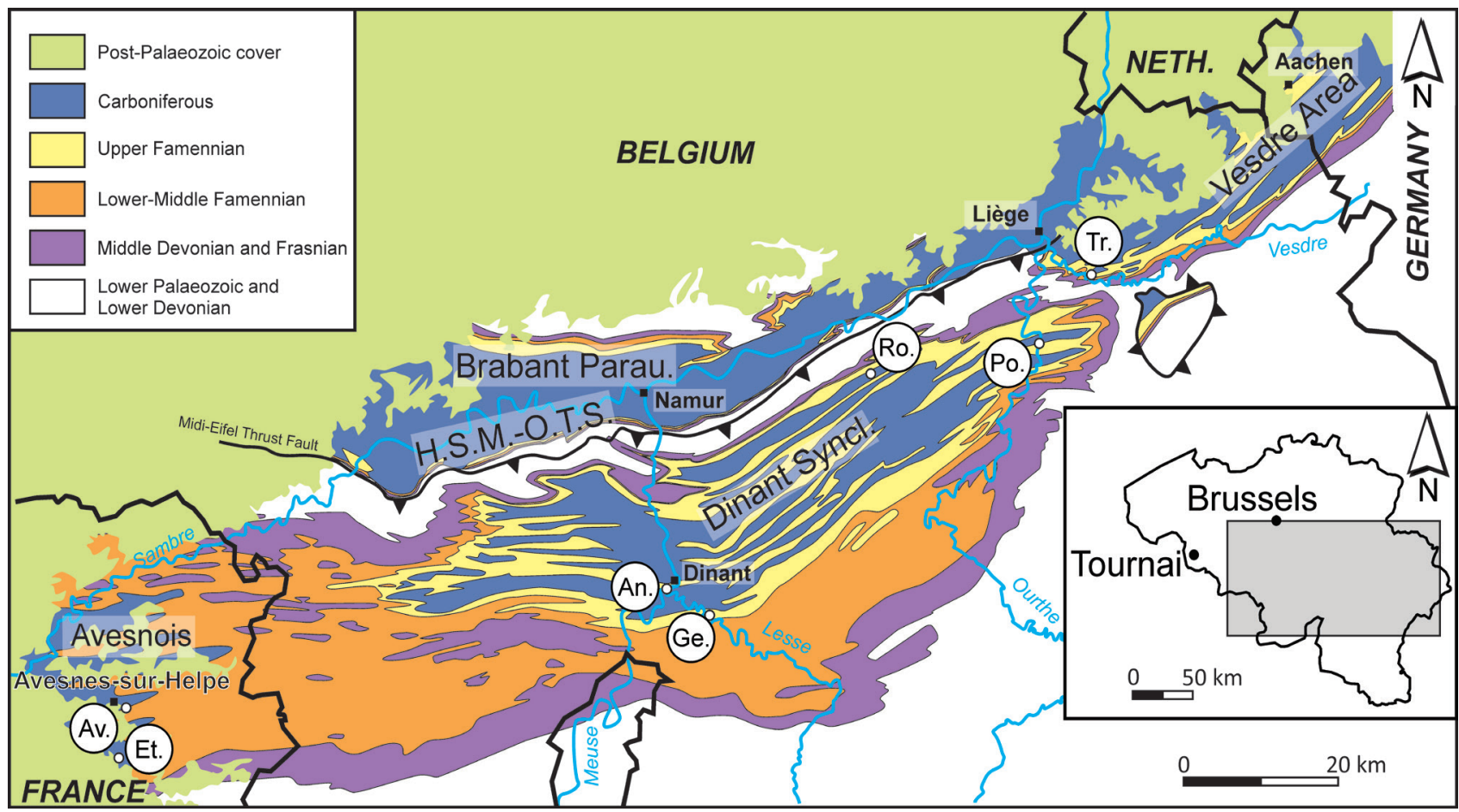

Figure 1. Location and schematic geological map of southern Belgium with indication of the sampled localities (modified from de Béthune, 1954 and Denayer et al., 2012). The Brabant Parautochthon and the Haine-Sambre-Meuse Overturned Thrust Sheets were formerly known as the Namur Synclinorium (see Belanger et al., 2012 for more information). Abbreviations: An., Anseremme; Av., Avesnelles; Et., Etrœungt; Ge., Gendron-Celles; H.S.M.-O.T.S., Haine-Sambre-Meuse Overturned Thrust Sheets; Neth., the Netherlands; Parau., Parautochthon; Po., Pont-deScay; Ro., Royseux; Syncl., Synclinorium; Tr., Trooz.

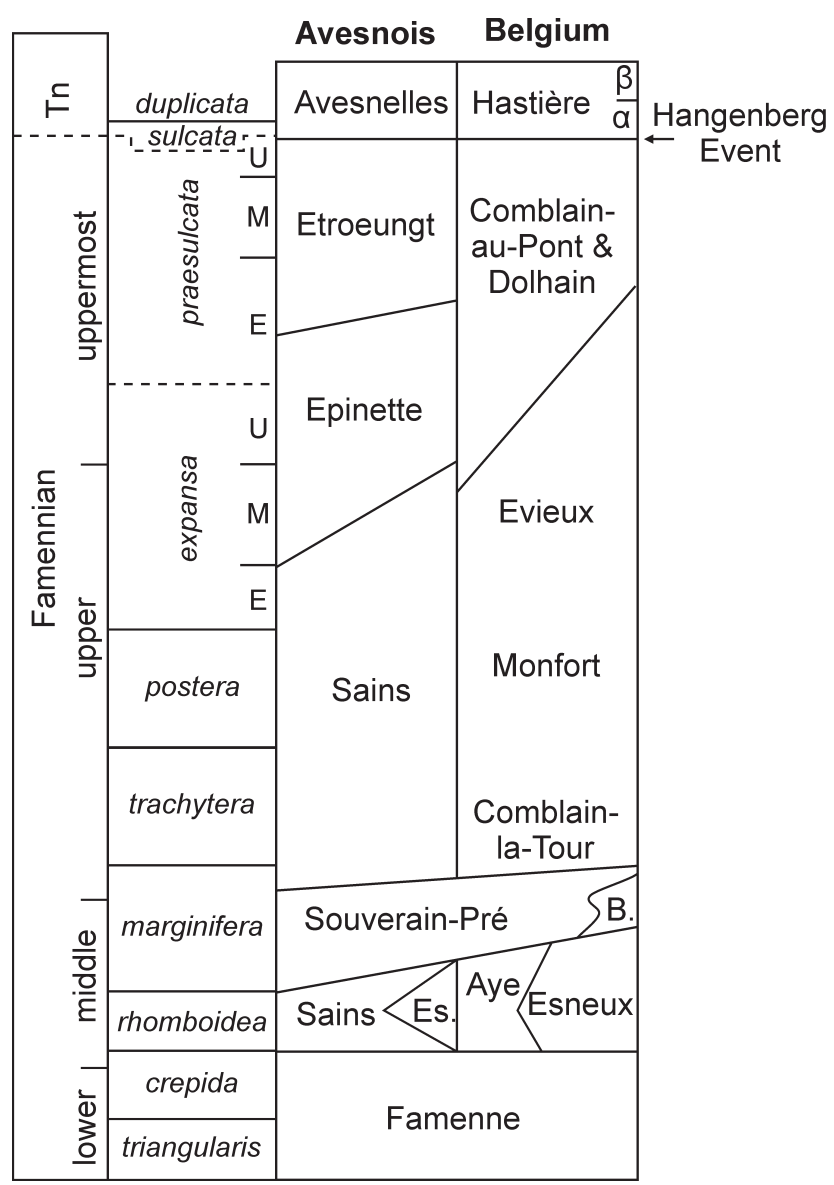

Figure 2. Partial and simplified lithostratigraphical scheme of the Famennian in the Avesnois and southern Belgium (modified from Poty, 1999). In Belgium, the Etrœungt Formation is recognized on the southern flank of the Dinant Synclinorium and passes eastwards to the Comblain-au-Pont Formation; the Dolhain Formation is recognized in the Vesdre area (Fig. 1). Abbreviations: B., Baelen Member; E, Early; Es., Esneux Formation; M, Middle; Tn, Tournaisian; U, Upper.
The material from the Avesnois originates from several sections, notably the Le Parcq (AV-EP) and Jean-Pierre (AVEJ) quarries in Etrœungt, the Avesnelles railway section (AVAT, CB-AT) and several temporary ones in the Godin quarry (formerly the Bocahut quarry) at Avesnes (see also figs 1-3 in Brice et al. (2013) for the location of Flaumont, Guersigny, Semeries and Solre-le-Château, from where originate some specimens of the MGL collections illustrated here, and references in Mistiaen et al. (2013)). The Le Parcq quarry is the historical section of the Etrœungt Formation, which was first described by Gosselet (1857), but as stressed notably by Mistiaen et al. (2013), the base and the top of the formation are not exposed in this quarry (Fig. 3).

\subsection{Southern Belgium}

In Belgium, brachiopods briefly discussed here have been obtained from the Etrœungt Formation at Anseremme (e.g. Conil, 1968; Poty et al., 2014) and Gendron-Celles (e.g. Conil, 1968), from the Comblain-au-Pont Formation at Royseux (e.g. Austin et al., 1970), Chanxhe (e.g. Conil et al., 1964; Maziane-Serraj et al., 2007) and Pont-de-Scay (e.g. Poty et al., 2011) (Fig. 1). The Comblain-au-Pont Formation (Fig. 2) reaches c. $50 \mathrm{~m}$ in thickness in the Ourthe valley (Thorez et al., 1974) and is composed of green shales and siltstones interbedded with argillaceous or calcareous, micaceous sandstones, and limestones (Bultynck \& Dejonghe, 2002). The latter are frequently crinoidal and become more abundant at the top of the formation. The presence of stromatoporoid biostromes (e.g. Conil et al., 1964; Aretz \& Chevalier, 2007) is characteristic of this unit as is also the case for the Dolhain Formation (c. $35 \mathrm{~m}$ thick) occurring in the Vesdre area (Figs 1-2), notably at the Trooz quarry (Poty et al., 2011) (Fig. 1). Both formations are partly time-equivalents of the Etrœungt Formation from the Avesnois and the southern flank of the Dinant Synclinorium eastwards (Bultynck \& Dejonghe, 2002) (Fig. 1). Besides brachiopods, the macrofauna includes bryozoans (Tolokonnikova et al., 2015), rugose corals (Poty, 1999; Denayer et al., 2012), stromatoporoids (Conil, 1961) and trilobites (Richter \& Richter, 1933; Rome, 1936; Hahn in Dreesen et al., 1976). In Belgium, contrary to the 
(A) (B) (D)

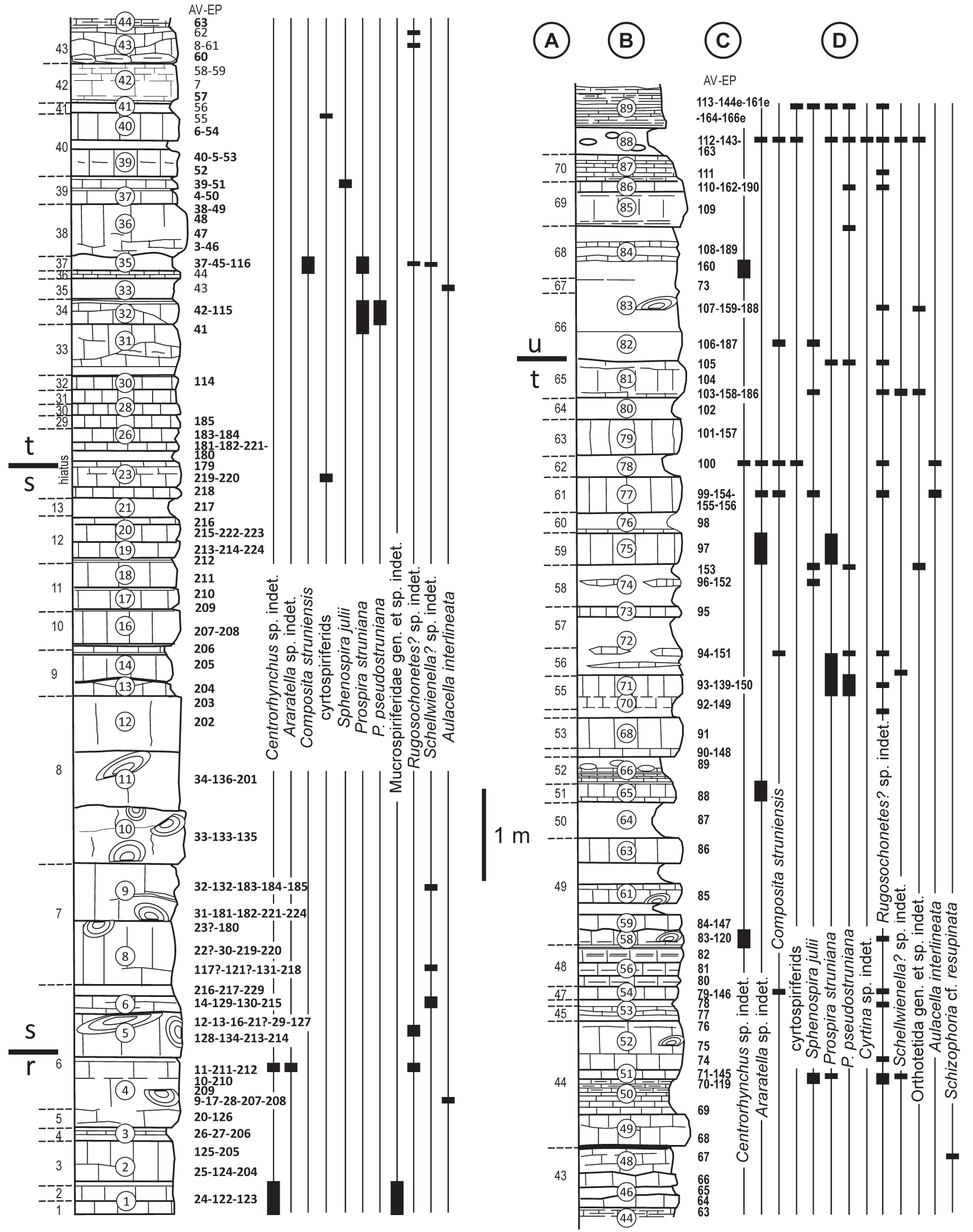

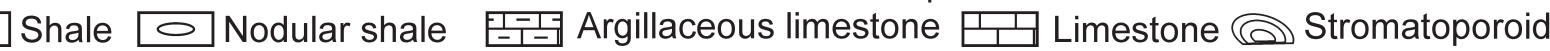

Figure 3. Lithological column of the Etrœungt Formation at the Le Parcq quarry (Etrœungt) (modified from Mistiaen et al., 2013) and distribution of the brachiopods (see also Brice et al., 2013, fig. 2). Abbreviations: A, correlation with bed numbering and the units recognized by Conil et al. (1964) in the Avesnelles railway section; B, lithological succession recognized by Mistiaen et al. (2013); C, location of the samples (AV-EP); D, distribution of the brachiopods. 
rest of the Famennian succession consisting of siliciclastics, except the mid-Famennian nodular limestones of the Souverain-Pré Formation and its carbonate Baelen Member (Dreesen et al., 2013) (Fig. 2), the uppermost Famennian is characterized by the re-occurrence of carbonate facies that have disappeared since the end of the Frasnian and also of corals and stromatoporoids. Rugose and tabulate corals were particularly rare and low diversity during the lower Famennian-upper Famennian interval, but several radiations have been discriminated during the Strunian (Poty, 1999; Denayer et al., 2012).

The Devonian-Carboniferous boundary has been intensively studied in southern Belgium both from the palaeontological and sedimentological viewpoints (e.g. Conil et al., 1964, 1986; Van Steenwinkel, 1990; Poty, 1999; Poty et al., 2006). Some brachiopods such as Araratella moresnetensis (de Koninck, 1887) and Sphenospira julii (Dehée, 1929) are useful uppermost Famennian guides but, in general, those of the base of the Tournaisian remain poorly known due to their scarcity and the difficulties extracting them from the carbonate matrix. They are more abundant at the top of the uppermost Famennian although their diversity is relatively low (Conil et al., 1986). In the Anseremme section (Fig. 1; see log in Poty et al., 2014), which has been selected as the neostratotype of the base of the Hastarian Substage (Hance \& Poty, 2006), the base of the Carboniferous, and thus that of the Tournaisian Stage and the Hastarian Substage, is placed at the base of the bed 162 (e.g. Hance \& Poty, 2006; Poty et al., 2014). This boundary was drawn on the basis of the disappearance of reworked 'Devonian' fauna and conodonts of the praesulcata Zone, because above bed 159 in this section there was no palaeontological criterion for defining the base of the Hastarian (Conil et al., 1986; Poty et al., 2014). According to Poty et al. (2014), at Anseremme, the Hangenberg Extinction Event, although it is not marked lithologically, has to be placed at the top of the Etrœungt Formation notably on the basis of the extinction of the representatives of the foraminifer genus Quasiendothyra and the ostracod genus Cryptophyllus as well as the presence of reworked Strunian rugose corals at the base of the bed 159, which corresponds to the first bed of the Hastière Formation. At Royseux (e.g. Austin et al., 1970; Conil et al., 1986) (Fig. 1), brachiopods are abundant in an $80 \mathrm{~cm}-$ thick calcareous sandstone bed (bed 104; see log (section Huy 15) in Austin et al., 1970 and Denayer et al., 2015) which has been correlated with the Hangenberg Sandstone (e.g. Kaiser et al., 2011) by Mottequin \& Poty (2014). This bed includes several horizons rich in dissociated valves of orthotetides, productides (chonetidines and productidines), rhynchonellides (Araratella moresnetensis) and spiriferides (e.g. Sphenospira julii).

\section{Taxonomic notes on some brachiopods from the Franco-Belgian Basin}

In this chapter, brachiopods, mainly those from the Avesnois, are briefly discussed in the light of re-examination of the material investigated by Dehée (1929) complemented by our own collections. A new spiriferide species is systematically described in the following chapter.

\subsection{Strophomenides}

Brice et al. (2013, pl. 4, figs A-B) illustrated an incomplete specimen identified as Leptagonia cf. analoga (Phillips, 1836) from the Avesnelles railway section. It is part of the old collections of the Musée d'Histoire naturelle de Lille and may have been collected within the Epinette Formation, and not from the Etrœungt Formation. Anyway, Gosselet (1860) reported 'Leptaena rhomboidalis' in the shales with some beds of limestone that are overlain by the 'Etrœungt Limestone', i.e. the Epinette Formation. Moreover, no strophomenides were recognized in our own collections from the Etrœungt Formation in the Avesnois. Demanet (1958) reported Phillips' species in the uppermost Famennian of Belgium.
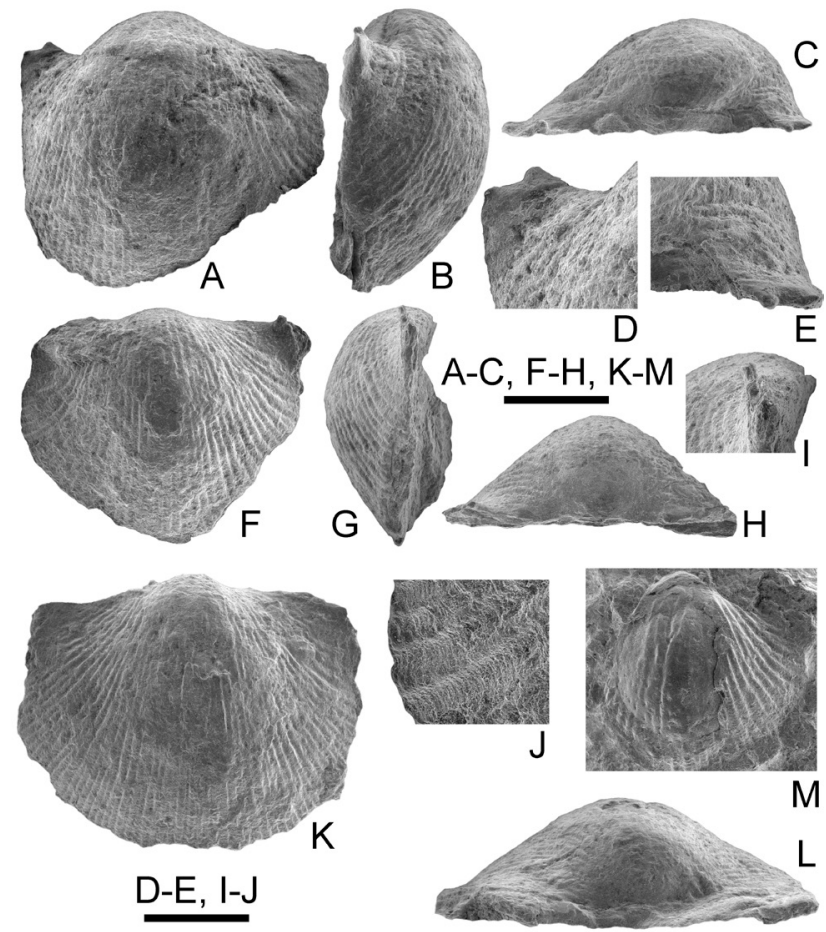

Figure 4. Rugosochonetes? sp. indet., Etrœungt Formation. A-E. GFCL 2233, incomplete and slightly distorted ventral valve in ventral, lateral and posterior views, and detail of the hinge spines, Le Parcq quarry (AV-EP100), Etrœungt. F-J. GFCL 2221, almost complete ventral valve in ventral, lateral and posterior views, close-up of the hinge spines and of the microlines, Le Parcq quarry (AV-EP111), Etrœungt. K-L. GFCL 2220, almost complete ventral valve in ventral and posterior views, Le Parcq quarry (AV-EP111), Etrœungt. M. GFCL 2222, partly exfoliated ventral valve showing traces of myophragm, Le Parcq quarry (AV-EP145), Etrœungt. Scale bars $=1 \mathrm{~mm}(\mathrm{~A}-\mathrm{C}$, F-H, K-M), $0.5 \mathrm{~mm}$ (D-E, I-J).

\subsection{Productides}

Rugosochonetes? sp. indet. (Figs 3, 4). In the Avesnois, small-sized and capillate chonetidines (c. 6 capillae per $0.5 \mathrm{~mm}$ at the anterior margin, numerous microlines (Fig. 4J)) with few hinge spines are relatively common within the Etrœungt Formation, notably at the Le Parcq quarry (Fig. 3), but also in the Avesnelles railway section and in the Godin quarry (Avesnes). Their ventral internal morphology is partly unknown as only one specimen shows traces of myophragm (Fig. 4M) whereas data related to the dorsal one are lacking. They are assigned tentatively to Rugosochonetes Sokolskaya, 1950. This genus was reported at the top of the uppermost Famennian and in the basal Hastarian by Conil et al. (1986). Some poorly preserved chonetidines were recently collected at Gendron-Celles (bed 47) and Royseux (bed 104) (Fig. 1). In the latter, they are associated with rhynchonellides (Araratella moresnetensis), orthotetides and productidines (Spinocarinifera inflata (Sokolskaya, 1948) and S. aff. lotzi (Paeckelmann, 1931) according to Legrand-Blain (1995)).

Productidina. In north-western France, Productidina from the Epinette and Etrœungt formations are still poorly known, contrasting with those from the limestones of the Avesnelles Formation. Brice (in Milhau et al., 1997) reported the presence of Semiproductus irregularicostatus (Krestovnikov \& Karpyshev, 1948) (det. M. LegrandBlain) within the Etrœungt Formation in a section formerly exposed in the Godin quarry, which has disappeared now. The following species were obtained from the Avesnelles Formation according to Legrand-Blain (1991): Spinocarinifera (S.) nigra (Gosselet, 1888), which occurs only in the middle part of this lithostratigraphic unit, Sentosia senta (Bublichenko in Bublichenko \& Nikitina, 1955) and Ovatia laevicosta (White, 1860). Note that the 
Avesnelles Formation is the stratum typicum of Productus heberti de Verneuil (in Hébert, 1855) according to Gosselet (1860, 1880, 1888), but this species has never been illustrated and remains doubtful. In southern Belgium, the most recent data related to the Productidina from the uppermost Famennian and the base of the Hastarian were provided by Legrand-Blain (1991, 1995), who reported the presence of Hamlingella goergesi (Paeckelmann, 1931) and Mesoplica (s.l.) nigeraeformis (Martynova, 1961) in the uppermost Famennian. The lowermost part of the Hastière Formation (uppermost Famennian), according to Conil et al. (1986) and Legrand-Blain (1991), yielded Whidbornella pauli (Goldring, 1957), Spinocarinifera inflata, and $S$. aff. lotzi. According to Legrand-Blain (1995), the specimens from the Hastière Formation identified as 'Hamlingella aff. goergesi' by Demanet (1958) correspond to poorly preserved external moulds which are not identifiable while those assigned to 'Productella caperata' by the same author belong to an unidentified species of Piloricilla.

\subsection{Orthotetides and orthides}

The representatives of both orders present in the upper and uppermost Famennian in the Avesnois, which were discussed by Dehée (1929), have been recently revised by Brice et al. (2013) who reported Schellwienella? sp. indet., Orthotetida gen. et sp. indet., Aulacella interlineata (Sowerby, 1840), and Schizophoria cf. resupinata (Martin, 1809); their range in the Le Parcq quarry is illustrated in Fig. 3. The contemporaneous orthotetides and orthides from Belgium listed by Demanet (1958) need to be revised.

\subsection{Rhynchonellides}

Centrorhynchus sp. indet. (Figs 3, 5H-K). Recent samplings in several sections exposing the Etrœungt Formation in the Avesnois, including the Le Parcq quarry, did not reveal the presence of Rhynchonella letiensis Gosselet, 1879, which was previously reported in the Etrœungt Zone by Dehée (1929) on the basis of material poorly stratigraphically constrained. Gosselet's species was assigned by Sartenaer (1970) to his new genus Centrorhynchus and is characteristic of the shaly middle-upper Famennian Sains Formation (Fig. 2). It appears that the single specimen illustrated by Gosselet (1880: pl. 5, fig. 10-10a) is lost, but all the specimens figured by this author in 1887 are housed at the Musée d'Histoire naturelle de Lille. Two of them (MGL 4186 (Fig. 5A-B; Gosselet, 1887, pl. 1, fig. 10), MGL 4188 (Fig. 5C-G; Gosselet, 1887, pl. 1, fig. 9) are for the first time photographically illustrated herein. Nonetheless, the revision of this species, in which several species or subspecies may be discriminated (C. gr. letiensis sensu Sartenaer 1968, 1972), is beyond the scope of this paper. The specimens from the Etrœungt Formation recently collected (Fig. 5H, K) as well as those from contemporaneous levels from southern Belgium can be assigned to Centrorhynchus notably on the basis of their strong and simple costae, but are clearly smaller than C. letiensis (Fig. 5A-G). The distribution of the genus within the Avesnelles Formation (Fig. 5I-J) still remains poorly known.

Araratella spp. (Figs 3, 5K-P). Among the rhynchonellides, the genus Araratella Abramian, Plodowski \& Sartenaer (in Sartenaer \& Plodowski, 1975) is one of the best guides to the uppermost Famennian in Eurasia (see Sartenaer \& Plodowski, 2003 for more details). Araratella moresnetensis (Fig. 5L-P) is abundant in the Dinant Synclinorium and the Vesdre area (Sartenaer \& Plodowski, 1975, 2003) and has been reported notably at the top of the Comblain-au-Pont Formation at Royseux (Conil et al., 1986). In the Avesnois, Brice (in Milhau et al., 1997) reported Araratella sp. in the Le Parcq quarry at Etrœungt but the genus also occurs elsewhere in the Avesnois (Godin quarry and Avesnelles railway section). One of these small-sized specimens, characterized by costae increasing by bifurcation (contrary to Centrorhynchus sp. indet.), is illustrated here (Fig. 5K). The material from north-western France at hand is too fragmentary and poorly preserved for description.
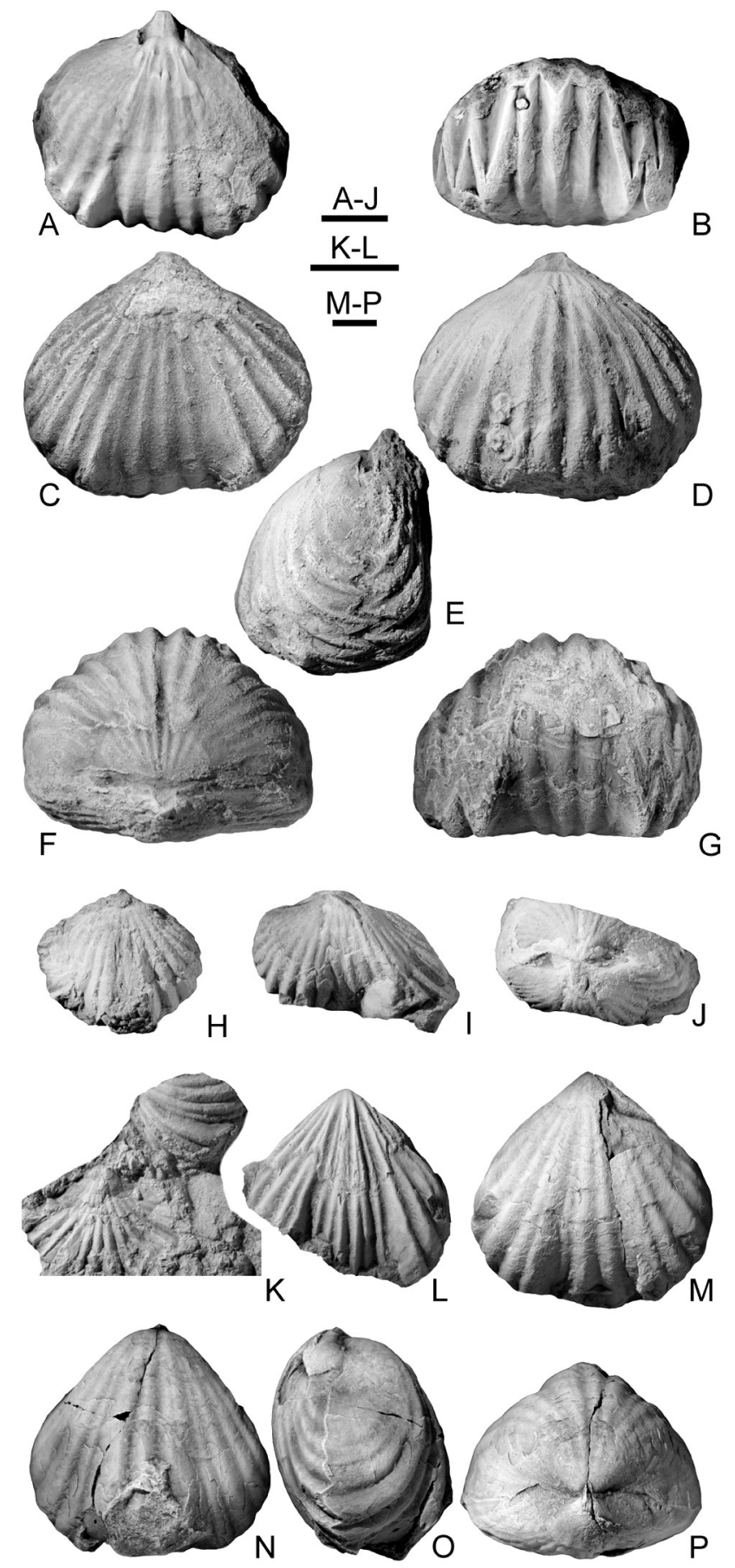

Figure 5. A-G. Centrorhynchus letiensis (Gosselet, 1879), Sains Formation. A-B. MGL 4186, incomplete internal mould in ventral and anterior views, Solre-le-Château. C-G. MGL 4188, complete specimen in ventral, dorsal, lateral, posterior and anterior views, Sains railway section. H-K. Centrorhynchus sp. indet. H. GFCL 2227, dorsal valve, Etrœungt Formation, Godin quarry (AV-BO 166), Avesnes. I-J. GFCL 2228, incomplete specimen in ventral and posterior views, Avesnelles Formation, Avesnelles railway section. K. GFCL 2229, flattened ventral valve (bottom) associated with an incomplete dorsal valve of Araratella sp. indet. (top), Etrœungt Formation, Le Parcq quarry (AV-EP 11), Etrœungt. L-P. Araratella moresnetensis (de Koninck, 1887), Comblain-au-Pont Formation, Chanxhe. L. ULg 3501/1, almost complete ventral valve. M-P. ULg $3501 / 2$, almost complete specimen in ventral, dorsal, lateral and posterior views. Scale bars $=5 \mathrm{~mm}$. 


\subsection{Athyridides}

Cleiothyridina sp. indet. The ornamentation of the specimens described by Dehée (1929: pl. 4, figs 4-6) as 'Athyris concentrica von Buch' clearly includes fragments of spiny projections that are typical of representatives of the subfamily Cleiothyridininae. They are assigned to Cleiothyridina Buckman, 1906 rather than to Crinisarina Cooper \& Dutro, 1982, whose representatives are more compact and present a subpentagonal outline. However, the specimens illustrated by Dehée (1929) are very similar if not conspecific with a undescribed Cleiothyridina species from the lower Famennian (Basilicorhynchus basilicus gerardimontis Zone) of the southern flank of the Dinant Synclinorium. We have some doubts about the age of Dehée's specimens as similar specimens have not been found in recent field collections. Only some small-sized and poorly preserved specimens (not illustrated here) that may be assigned to Cleiothyridina have been obtained so far within the Etrœungt Formation (Godin quarry, AV-BO 165). Note that the representatives of the subfamily Cleiothyridininae rank among the dominant elements of the Famennian brachiopod faunas, especially with Crinisarina in the lower Famennian of northern France and southern Belgium (Mottequin, 2008a) but seems to be absent in the mid to uppermost Famennian of these regions, whereas Cleiothyridina is known from the Givetian in the Boulonnais (Brice et al., 2008) and from the Frasnian in the Dinant Synclinorium (Mottequin, 2008b).
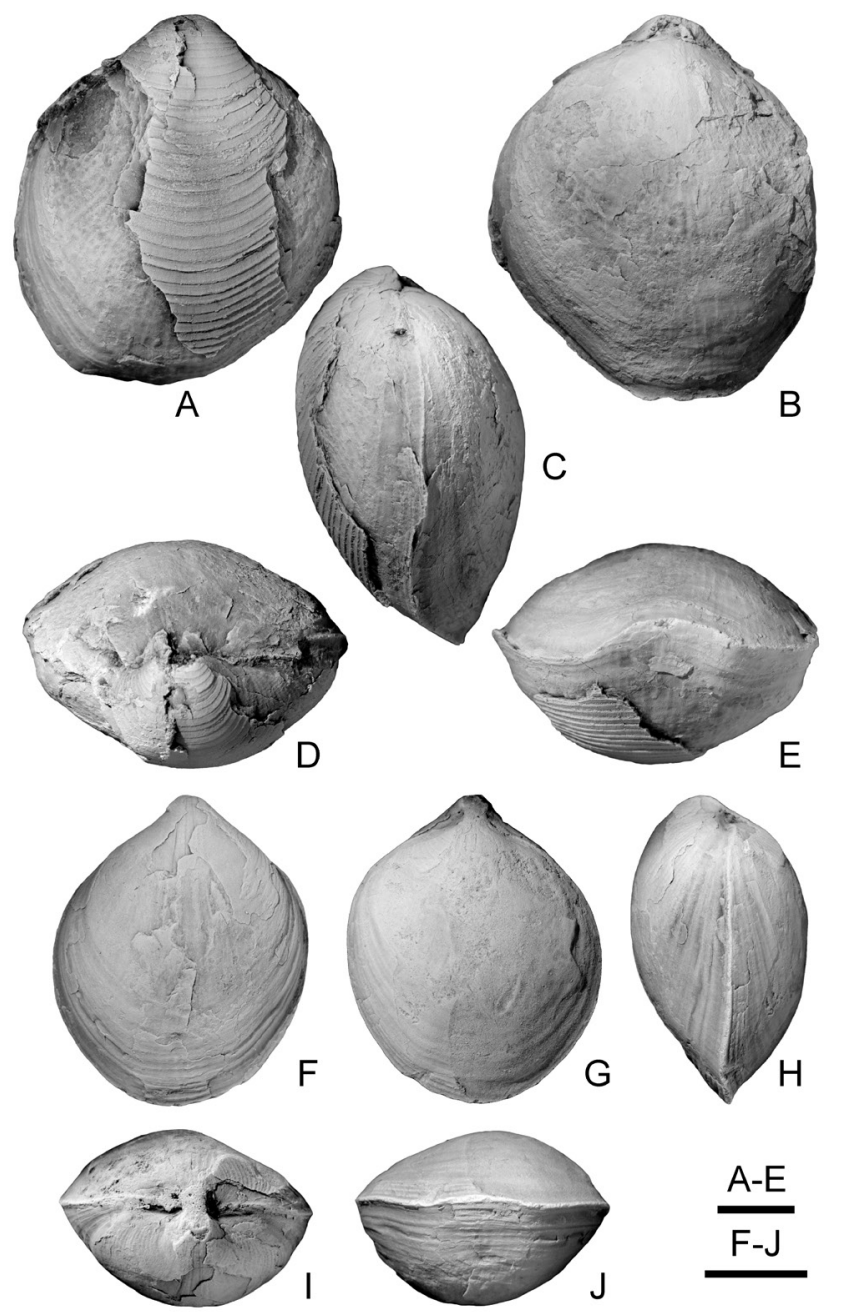

Figure 6. A-J. Composita struniensis (Dehée, 1929), Etrœungt Formation. A-E. GFCL 2235, slightly deformed articulated specimen in ventral, dorsal, lateral, posterior and anterior views, Godin quarry (AV-BO 44), Avesnes. F-J. MGL 29860/1, juvenile specimen in ventral, dorsal, lateral, posterior and anterior views, Etrœungt. Scale bars = $5 \mathrm{~mm}$.
Composita struniensis (Dehée, 1929) (Figs 3, 6). The type of Seminula struniensis Dehée, 1929, which was clearly identified by Dehée (1929, pl. 4, fig. 2), has not been found so far in the collections of the Musée d'Histoire naturelle de Lille; nor have the two other specimens illustrated by this author. Only two of the six specimens mentioned by Dehée (1929) are currently available and one of them (a juvenile, MGL 29860/1) is illustrated here (Fig. 6F-J). Brice (in Milhau et al., 1997) transferred this species to Composita Brown, 1845 as Seminula Hall \& Clarke, 1893 (non M'Coy, 1844) is considered a synonym of the former (Buckman, 1906). Based on Polish material from the Holy Cross Mountains considered as conspecific with Dehée's species by Halamski \& Baliński (2009), these authors assigned the species struniensis to Cleiothyridina as the Polish specimens display nicely preserved spinous projections. However, a specimen recently collected within the Etrœungt Formation displays large growth lamellae devoid of spiny projections (Fig. 6A) and thus cannot be assigned to any genus of the subfamily Cleiothyridininae and strongly suggests that the French and Polish material are not conspecific.

\subsection{Spiriferides}

Sphenospira julii (Dehée, 1929) (Figs 3, 7-8). This is one of the most emblematic species of the uppermost Famennian succession in the Franco-Belgian Basin; it is particularly abundant in some Belgian sections (e.g. Pont-de-Scay). In the Avesnois, the species is reported in the Etrœungt and Avesnelles formations by Legrand-Blain (1995) although its range within the latter has not been specified. In southern Belgium, it occurs in the Etrœungt, Comblain-au-Pont and Dolhain formations. Dehée (1929) introduced Spirifer julii in order to solve the problem of secondary homonymy created by the introduction of the specific name Spirifer gosseletti (sic) by Vaughan (1915) (non Spirifer gosseleti Béclard, 1887, a Pragian species assigned to Mauispirifer Allan, 1947 by Vandercammen (1963); its generic status has to be clarified according to Schemm-Gregory (2008)). The material from the Avesnois (Etrœungt Formation) was described and discussed by Nicollin $(2004,2008)$, but the question of the type specimens needs to be clarified as Nicollin (2008) and Halamski \& Baliński (2009) reported that the specimen MGL 1582 illustrated by Dehée (1929, pl. 2, fig. 5-5a; Fig. 7D-G) was the holotype. In the legend of his plate 2, Dehée (1929, pl. 2, figs 1-2) clearly identified the specimens MGL 1578 (an incomplete dorsal valve; Fig. 7H-I) and MGL 1579 (an almost complete ventral valve; Fig. 7A-C) as 'type[s] de l'espèce'. Following the Article 72.4.6 of the International Code of Zoological Nomenclature (fourth edition, 1999), both specimens constitute the type series. According to the Art. 74 of the Code, the specimen MGL 1579 is herein selected as the lectotype of Spirifer julii Dehée, 1929, whereas the specimen MGL 1578 becomes a paralectotype.

None of the specimens display the stegidium occluding the delthyrium that is observed in the type species of Sphenospira Cooper, 1954, but this is most probably due to the poor preservation of the material. Most of the available specimens correspond to dissociated valves indicating they suffered transport. To our knowledge, the first assignments to Cooper's genus date back to Ivanova (1960) and Sarycheva et al. (1963).

Prospira struniana (Gosselet, 1879) (Figs 3, 9A-P). The material from the Avesnois was revised by Dehée (1929), Vandercammen (1956) and Brice (1997). Full illustrations of the lectotype (MGL 1591; Dehée 1929: pl. 3, fig. 5; Fig. 9FJ) chosen by Brice (1997) and of two paralectotypes (MGL 1590 (Dehée, 1929: pl. 3, fig. 4; Fig. 9A-E) and MGL 1592 (Dehée, 1929: pl. 3, fig. 6; Fig. 9K-O) are provided herein. The presence of this easily recognizable species in southern Belgium was briefly discussed by Vandercammen (1956) and Conil et al. (1986); one specimen from the Comblain-au-Pont Formation (Pont-de-Scay) is illustrated herein (Fig. 9P).

Martiniidae gen. et sp. indet. (Fig. 9Q). One incomplete ventral internal mould (GFCL 2236; Etrœungt Formation, Godin quarry) with shelly remains is characterized by the 


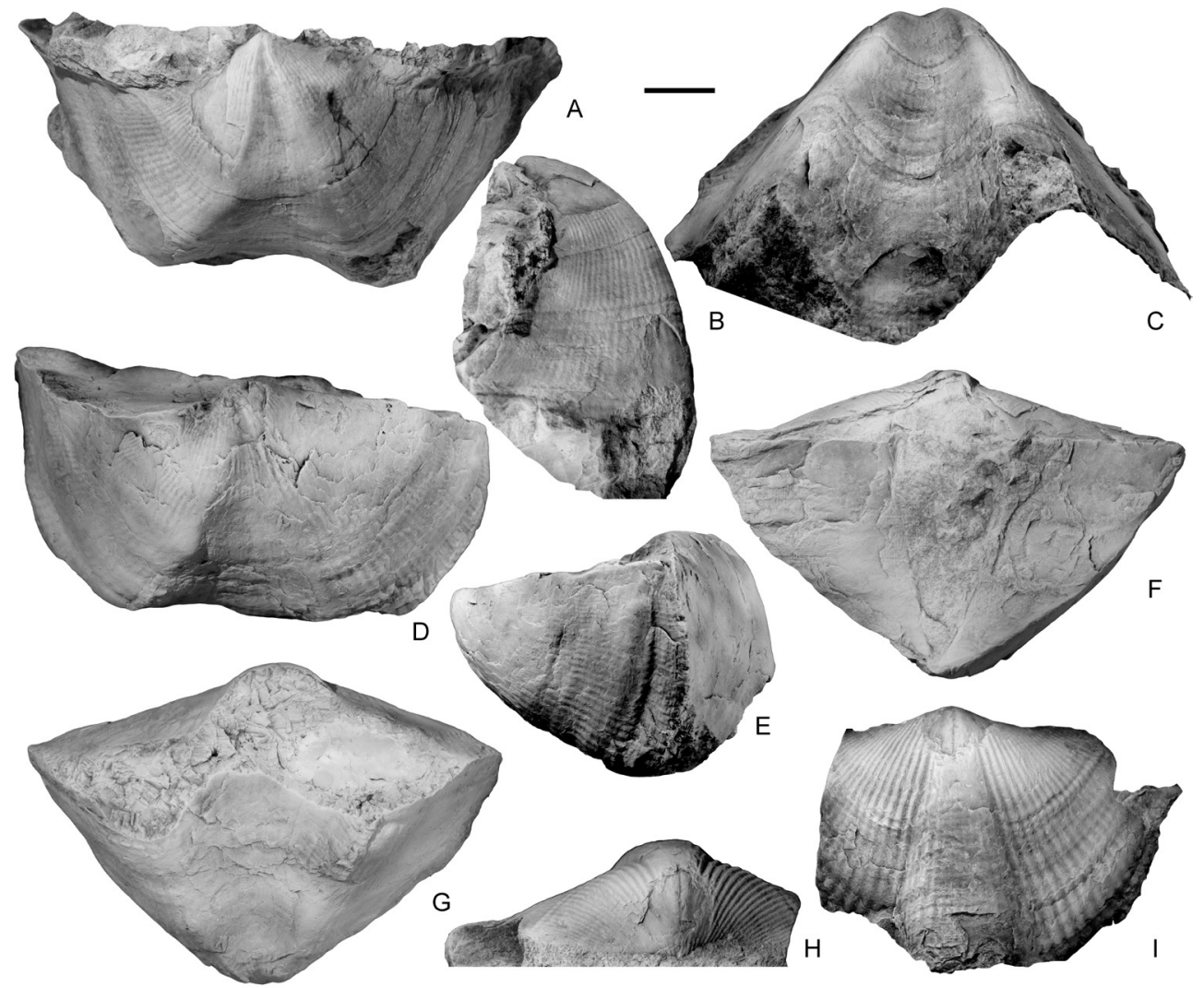

Figure 7. A-I. Sphenospira julii (Dehée, 1929), Etrœungt Formation. A-C. MGL 1579 (lectotype), ventral valve in ventral, lateral and anterior views, Flaumont (Dubar quarry). D-G. MGL 1582, almost complete articulated specimen in ventral, lateral, posterior and anterior views, Etræungt. H-I. MGL 1578 (paralectotype), incomplete dorsal valve in posterior and dorsal views, Etrœungt. Scale bar $=10 \mathrm{~mm}$.

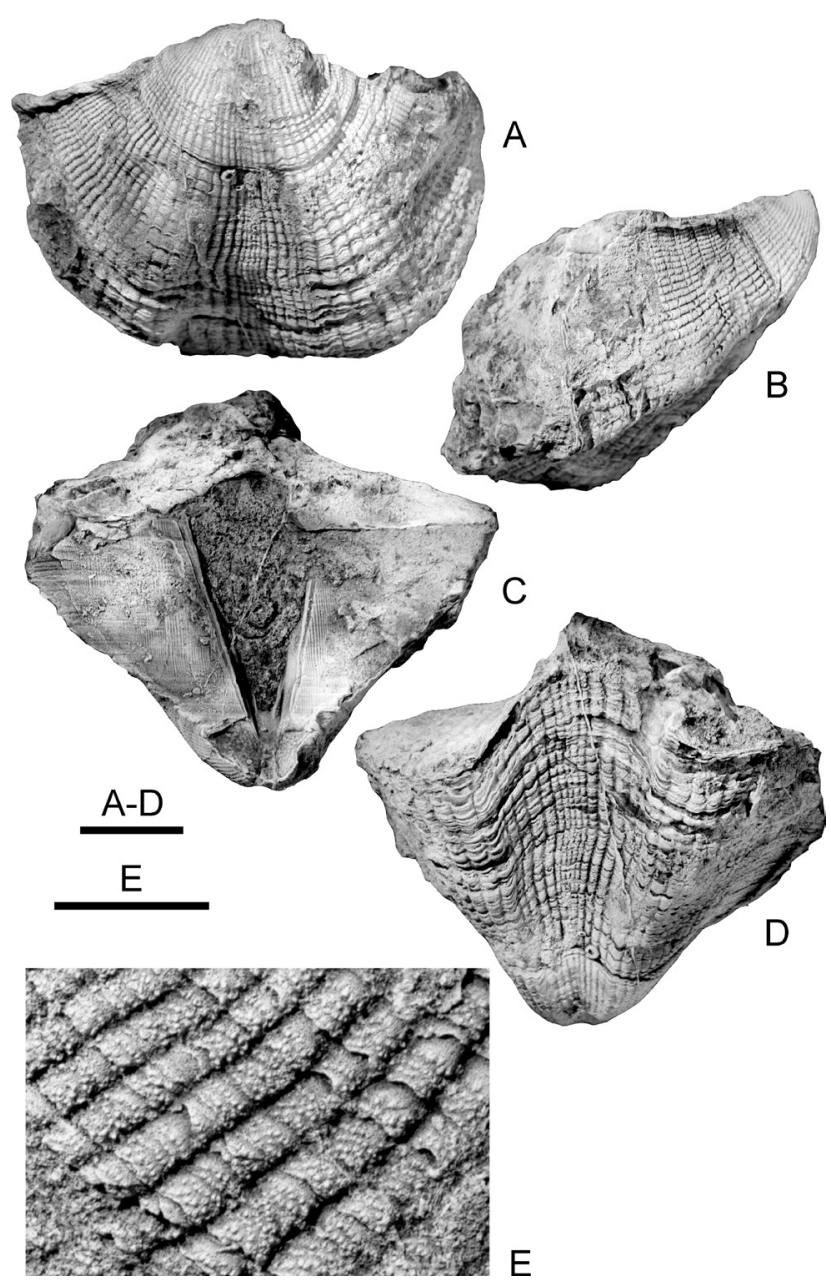

Figure 8. A-E. Sphenospira julii (Dehée, 1929), Dolhain Formation, Trooz quarry. IRScNB a13047, almost complete specimen (dorsal valve partly masked by carbonate matrix) in ventral, lateral, posterior and anterior views and close-up of the pustulose micro-ornament on the left ventral flank. Scale bars $=10 \mathrm{~mm}(\mathrm{~A}-\mathrm{D}), 2.5 \mathrm{~mm}(\mathrm{E})$. following features: valve medium-sized, wider than long, rounded subpentagonal in outline with rounded cardinal angle; sulcus poorly developed, shallow; interarea moderately high; flanks and sulcus smooth; dental plates thin, slightly divergent; muscle field long, not excavated. The general shape and the ventral internal features suggest an assignment to the family Martiniidae.

Elythidae gen. et sp. indet. (Fig. 9R). Only one incomplete, slightly crushed ventral internal mould (GFCL 2237; Etrœungt Formation, Godin quarry) with shelly fragments is identified as such and described as follows: valve medium-sized, wider than long, subelliptic in outline, convex; sulcus poorly defined, shallow; interarea cata-apsacline, moderately high; dental plates thin, long, slightly divergent; median septum very long; muscle field not excavated, triangular in outline; muscle scars poorly preserved. Ornamentation of concentric, closely spaced lamellae bearing biramous spines.

It is currently not possible to confidently assign this specimen to an elythid genus as the absence of dorsal valve cannot permit to discuss the presence (or otherwise) of a ctenophoridium. Note that the genus Kitakamithyris Minato, 1951, and more particularly the species $K$. microgemma (Phillips, 1841), was reported but not illustrated by Conil et al. (1986) within the topmost part of the Comblain-au-Pont Formation in eastern Belgium.

Mucrospiriferidae gen. et sp. indet. (Figs 3, 9S-W, 10). The specimens previously identified as Tylothyris laminosa (M'Coy, 1841) by Dehée (1929, pl. 3, figs 12-14) were most probably obtained from the Epinette Formation, as suggested by the material collected in the Avesnelles railway section by C. Brousmiche within this formation (unit J; see Conil \& Lys, 1968); some rare poorly preserved specimens were recently collected at the Le Parcq quarry (Etrœungt Formation). Their main features are the following: growth lamellae coarse, shell widest at hinge line; fold and sulcus smooth, well-defined; 9-10 simple and rounded costae per flank; shell impunctate; hinge line not denticulate; dental plates thickened; delthyrial plate very short; ctenophoridium and crural bases present. They have to be rejected from Tylothyris North, 1920 as they are devoid of a ventral septum and their coarse growth lamellae are clearly less imbricate than in M'Coy's species, of which wellpreserved Tournaisian-aged specimens from the Tournai area 
(Fig. 1) are illustrated here (Fig. 9X-Y) in order to facilitate comparison - see also Brunton (1984) and Mottequin's (2010) illustrations of Irish material from the Tournaisian Hook Head Formation, its stratum typicum. They are assigned to the family Mucrospiriferidae (Delthyridoidea) on the basis of their external (growth lamellae well-defined) and internal (ctenophoridium present; crural plates absent) morphology, and more precisely to the subfamily Mucrospiriferinae as they lack a ventral septum. However, they cannot be assigned to one of the genera included in this subfamily by Johnson \& Hou (2006). Further material is required to reach a better identification. They also display external similarities (e.g. size, outline, lamellose growth lamellae) with Spirifer (Spinocyrtia) eupenensis Paeckelmann, 1942 from the middle Famennian Esneux Formation, but this species has to be revised.

Other spiriferides. Poorly preserved specimens assigned to the Cyrtospiriferidae subfamily (Fig. 3) have been collected in various outcrops within the Etroungt Formation, but additional and better preserved material is needed for a better identification. They differ markedly from Sphenospira julii (Dehée, 1929) by their low ventral interarea. The stratigraphic position of the specimens identified as Cyrtospirifer verneuilli
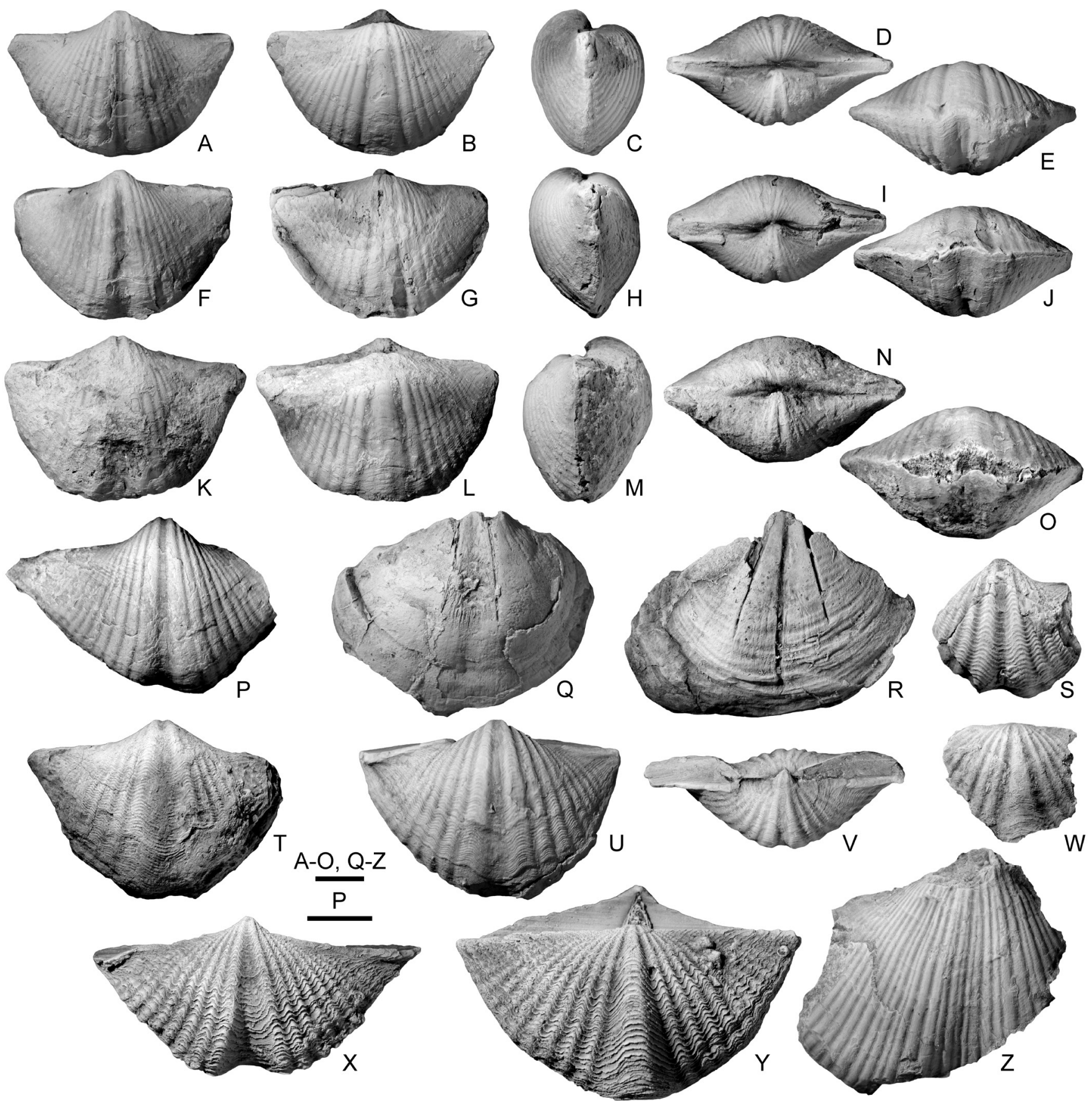

Figure 9. A-P. Prospira struniana (Gosselet, 1879). A-E. MGL 1590 (paralectotype), articulated specimen in ventral, dorsal, lateral, posterior and anterior views, Etrœungt Formation, Etrœungt. F-J. MGL 1591 (lectotype), slightly flattened articulated specimen in ventral, dorsal, lateral, posterior and anterior views, Etrœungt Formation, Etrœungt. K-O. MGL 1592 (paralectotype), articulated specimen in ventral, dorsal, lateral, posterior and anterior views, Etrœungt Formation, Etrœungt. P. ULg 3502/1, incomplete ventral valve, Comblain-au-Pont Formation. Pontde-Scay. Q. Martiniidae gen. et sp. indet., GFCL 2236, almost complete ventral internal mould, Etrœungt Formation, Godin quarry (AV-BO 143), Avesnes. R. Elythidae gen. et sp. indet., GFCL 2237, almost complete ventral internal mould, Etrœungt Formation, Godin quarry (AV-BO 143), Avesnes. S-W. Mucrospiriferidae gen. et sp. indet., most probably from the Epinette Formation (see discussion in the text). S. MGL 1599, incomplete ventral valve, Etrœungt. T. MGL 9565, almost complete ventral valve, Guersigny near Avesnes. U-V. MGL 1598, flattened specimen in ventral and posterior views, Etrœungt. W. MGL 1600, incomplete dorsal valve, Semeries (La Ronflette quarry). X-Y. Tylothyris laminosa (M'Coy, 1841), Tournai Formation (Tournaisian), Tournai area. X. IRScNB a13048, articulated specimen in ventral view. Y. IRScNB a13049, articulated specimen in dorsal view. Z. 'Spirifer tornacensis' fide Dehée (1929), MGL 1493, incomplete ventral valve, Etrœungt Formation (?), Etrœungt. Scale bars $=5 \mathrm{~mm}$. 


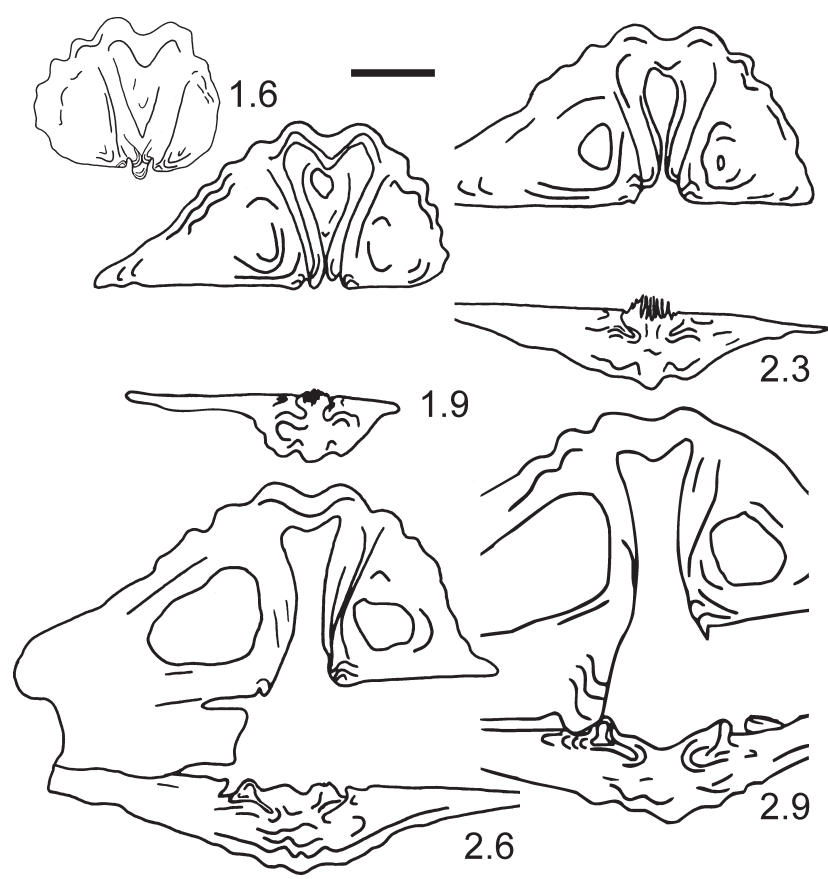

Figure 10. Transverse serial sections of Mucrospiriferidae gen. et sp. indet. Numbers refer to distances in $\mathrm{mm}$ from the top of the ventral umbo; GFCL 2226 from the Epinette Formation (unit J; see Conil \& Lys, 1968), Avesnelles railway section (AV-AT 11). Scale bar $=2 \mathrm{~mm}$.

by Dehée (1929) remains unclear. This is also the case for the specimens of Gosselet's collection (identified by Gosselet as 'Spirifer mosquensis') discussed but not illustrated by Dehée (1929), who assigned them to 'Spirifer tornacensis' (Fig. 9Z). All are fragmentary. On the flanks, the most internal costae increase by bifurcation as observed in the sulcus; their microornament consists of only strong capillae. In the absence of less fragmentary material, it is not possible to identify them at the generic level with certainty.

\subsection{Spiriferinides}

Cyrtina sp. indet. (Figs 3, 11A-H). Rare, small-sized specimens identified as such were obtained from the Etrœungt Formation. The main external features are the following: ventral interarea apsacline, high, almost flat; ventral beak not curved; sulcus and fold well-defined; tongue low, rounded, perpendicular to commissural plane; at least 4 costae per flank; growth lamellae rare. The preservation of this very limited material precludes detailed description and comparison. However, the discovery of Cyrtina in the uppermost Famennian of the Avesnois, and thus in the Franco-Belgian Basin, is important as it is the first report of this long-ranging genus within the Famennian succession of this basin. Neither Maillieux (1941a), nor Demanet (1958) reported the genus in the Famennian nor in the uppermost Famennian of southern Belgium, respectively. Mottequin (2008b), on the basis of Demanet (1958), who listed Cyrtina carbonaria (M'Coy, 1855) in the Viséan (Livian) of the Namur-Dinant Basin, claimed that the genus would re-occur not before the Livian after the late Frasnian crisis in Belgium, but M'Coy's species belong to the suessioid genus Davidsonina Schuchert in Schuchert \& LeVene, 1929. In reality, the presence of true Cyrtina within the Mississippian of the Namur-Dinant Basin was overlooked in the most recent faunal lists which date back to Demanet (1958) and Mortelmans (1969). This genus occurs within the Tournaisian Tournai Formation (Tournai area, Fig. 1) where it is represented by Cyrtina koninckiana (d'Orbigny, 1849), which is here illustrated photographically for the first time (Fig. 11IJ). It is markedly different from the Avesnois species in size, ribbing and profile of the ventral interarea.

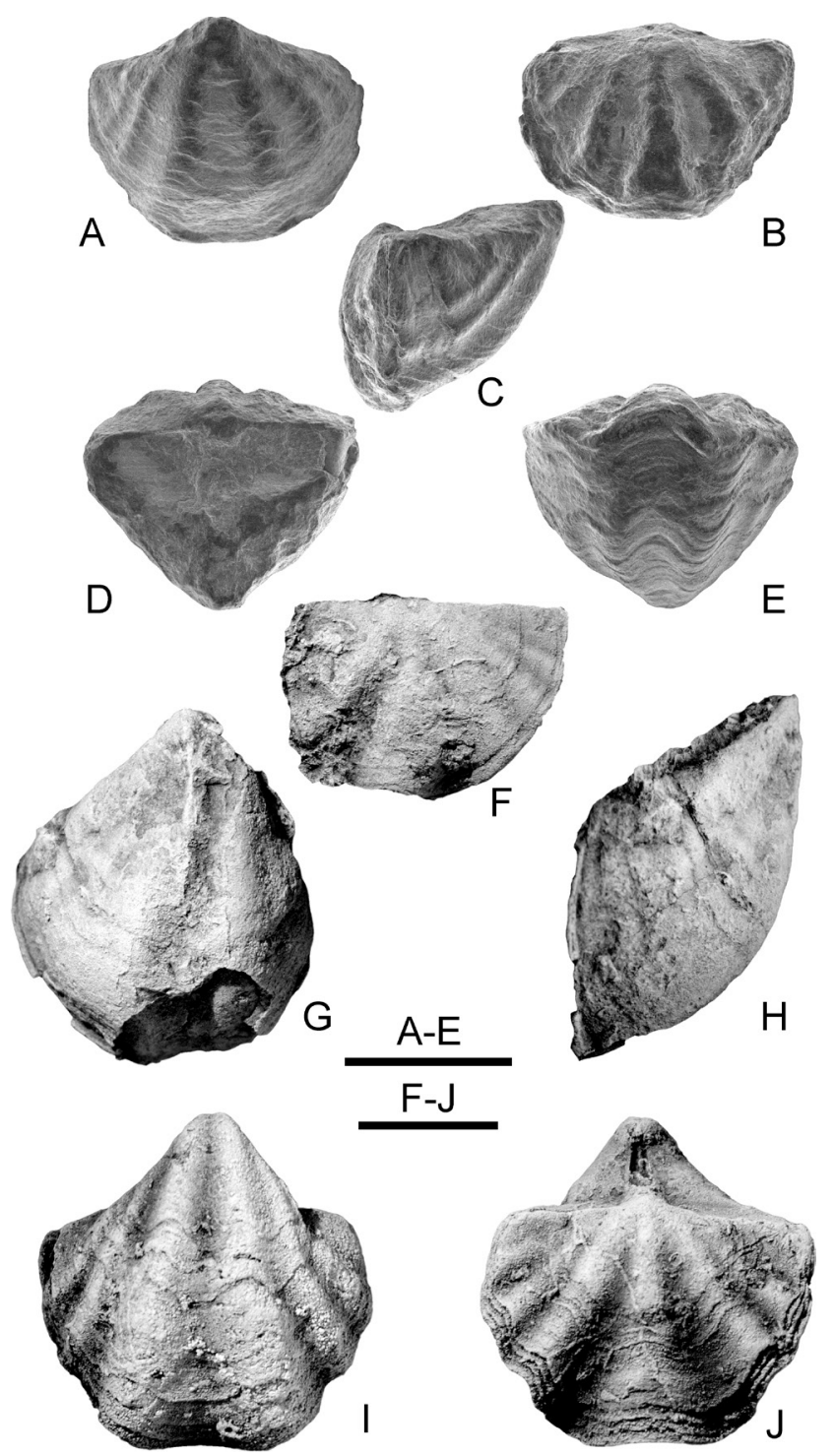

Figure 11. A-H. Cyrtina sp. indet., Etrœungt Formation. A-D. GFCL 2230, juvenile specimen in ventral, dorsal, lateral, posterior and anterior views (SEM), Godin quarry (AV-BO 186), Avesnes. E. GFCL 2231, dorsal valve, Avesnelles railway section (CB-AT u1/19). F-H. GFCL 2232, ventral valve in ventral and lateral views, Avesnelles railway section (CB-AT u1/21). I-J. Cyrtina koninckiana (d'Orbigny, 1849), IRScNB a13050, articulated specimen in ventral and dorsal views, Tournai Formation (Tournaisian), Tournai area. Scale bars $=5 \mathrm{~mm}$.

\section{Systematic palaeontology}

Order Spiriferida Waagen, 1883

Suborder Spiriferidina Waagen, 1883

Superfamily Spiriferoidea King, 1846

Family Spiriferidae King, 1846

Subfamily Prospirinae Carter, 1974

\section{Genus Prospira Maxwell, 1954}

Type species. Prospira typa Maxwell, 1954, from the Tournaisian of Stony Creek (Mt. Morgan District), Queensland (Australia).

Prospira pseudostruniana sp. nov.

Figs 3, 12-13

Derivation of name. From the Greek 'pseudos', meaning 'false' P. struniana.

Holotype. An almost complete dorsal valve, GFCL 2239 (AV-EP 105) (Fig. 12G-H). 


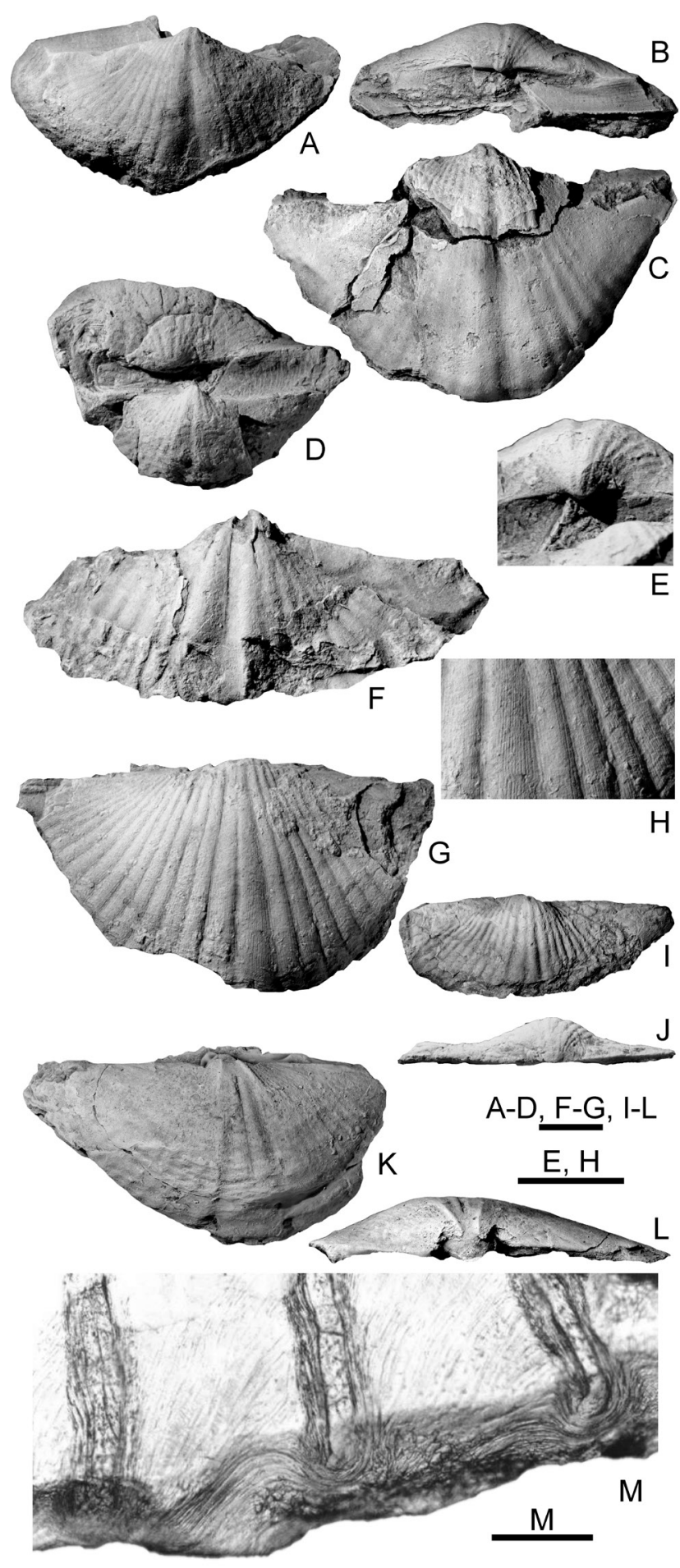

Figure 12. Prospira pseudostruniana sp. nov., Etrœungt Formation. A-B. GFCL 2245, slightly deformed, incomplete ventral valve in ventral and posterior views, Le Parcq quarry (AV-EP 139), Etrœungt. C. GFCL 2240, almost complete ventral valve, Le Parcq quarry (AVEP 143.1), Etroungt. D-E. GFCL 2244, articulate but incomplete and crushed specimen in posterior view and close-up of the deltidial plates, Godin quarry (AV-BO 143), Avesnes. F. GFCL 2225, incomplete ventral valve with shelly remains, Godin quarry (AV-BO 143), Avesnes. G-H. GFCL 2239, holotype, almost complete dorsal valve and close-up of the micro-ornament, Le Parcq quarry (AV-EP 105 section A4), Etrœungt. I-J. GFCL 2246, almost complete dorsal valve in dorsal and posterior views, Godin quarry (AV-BO 143), Avesnes. K-L. GFCL 2238, slightly deformed dorsal internal mould in dorsal and posterior views, Godin quarry, Avesnes (AV-BO 54). M. GFCL 2242, close-up of the denticulate hinge line, Le Parcq quarry (top of the section), Etroungt. Scale bars $=5 \mathrm{~mm}$ (except $\mathrm{M}=0.1 \mathrm{~mm}$ )

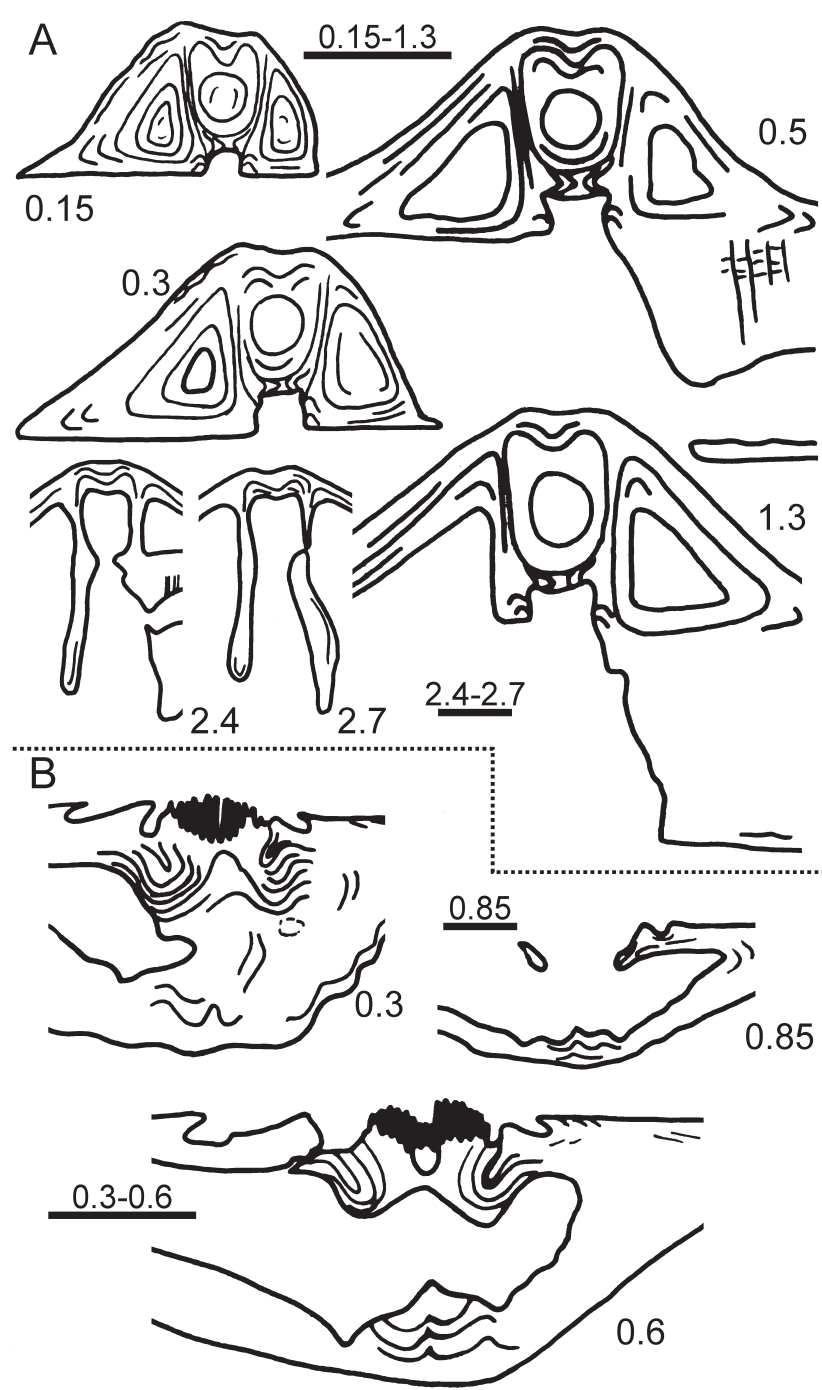

Figure 13. A-B. Transverse serial sections of Prospira pseudostruniana sp. nov., Etrœungt Formation, Le Parcq quarry (top of the section), Etrœungt. Numbers refer to distances in $\mathrm{mm}$ from the top of the ventral (A: GFCL 2242) and dorsal (B: GFCL 2243) umbones. Scale bars $=2 \mathrm{~mm}$.

Type locality and horizon. Beds 32-89, Etrœungt Formation, Le Parcq quarry (Etrœungt), uppermost Famennian (Figs $1-3)$.

Material. Le Parcq quarry (Etrœungt): 4 more or less complete ventral valves (GFCL 2245 (AV-EP 139)) (Fig. 12AB), GFCL 2240 (AV-EP 143.1) (Fig. 12C); GFCL 2242 (AVET 1.19, 1.18) (Figs 12M, 13A), 2 ventral internal moulds (AV-EP 42, AV-ET 1), 4 fragmentary dorsal valves (GFCL 2239 (AV-EP 105) (Fig. 12G-H); GFCL 2243(AV-ET 1.17) (Fig. 13B), AV-EP 151, 164). Godin quarry (Avesnes): 1 articulated but crushed specimen (GFCL 2244 (AV-BO 143) (Fig. 12D-E)), 10 more or less complete ventral valves (AV-BO 141, 142 ( 2 ventral valves), 143 (2 ventral valves), 143.6, 143.h, $145,159,211), 6$ more or less complete dorsal valves (AV-BO 55, 142, GFCL 2246 (AV-BO 143) (Fig. 12I-J), AV-BO 143, 143.2, 145), two dorsal moulds (AV-BO 143.13, GFCL 2238 (AV-BO 54) (Fig. 12K-L)). Avesnelles railway section: 2 dorsal valves (AV-AT u1/4, AT u1/24), 1 dorsal internal mould (AVAT 138).

Diagnosis. A species of Prospira of middle size (c. $31 \mathrm{~mm}$ wide), transverse subpentagonal in outline, biconvex, wider than long, presenting a clear dissymmetric outline. Ventral umbo prominent; ventral beak curved; ventral interarea moderately high, cata-apsacline; sulcus smooth, moderately 
deep, well-delimited by two widened ribs; fold low with a weak median groove, well-delimited by two grooves of width similar to that of the intercostal ones. Ten to 12 costae per flank, separated by very narrow intercostal grooves. Microornament of capillae. Dental plates subparallel, extrasinal; cardinal process concave; crural bases short.

Description. Shell medium-size (up to c. $31 \mathrm{~mm}$ in width), subtrapezoidal in outline, biconvex, wider than long, most probably widest at posterior margin (cardinal extremities broken), presenting a marked dissymmetric outline; anterior margin not emarginate; anterior commissure uniplicate. Of 14 ventral valves, 6 display a more developed left flank whereas in 8 valves, the opposite occurs; of 15 dorsal valves, 12 display a more developed right flank whereas in 3 valves, the contrary occurs.

Ventral valve inflated especially in its posterior part; umbo prominent; beak short and weakly curved on interarea; interarea high, cata-apsacline, slightly concave, striated, clearly delimited by ridges; delthyrium partly closed by deltidial plates (rarely preserved); sulcus smooth, moderately deep, delimited by two widened costae; tongue not observed, but most probably low. Interior with dental plates subparallel, short and slightly extrasinal; lateral cavities small; myophram long; hinge line denticulate; muscle field not excavated.

Dorsal valve subtrapezoidal in outline, wider than long, with flanks sloping gently towards the lateral commissures; interarea linear, flat, orthocline; fold well delimited by two grooves, almost flat with a weak median furrow originating in the posterior part of the valve. Interior with concave ctenophoridium bearing 13-15 lamellae; crural bases short; dental sockets small; myophram long.

Ten to 12 simple costae rounded in the posterior part of the valve, wider and flattened near the anterior margin; costae decreasing in size towards the lateral extremities where they become obsolescent and sometimes absent; intercostal grooves very narrow; micro-ornament of capillae.

\section{Dimensions. See Table 1.}

Discussion. These specimens undoubtedly belong to the genus Prospira on the basis of their medium size, their very transverse outline, their narrow sulcus and fold, their hinge line denticulate and their short dental plates.

P. pseudostruniana nov. sp. differs from the Tournaisian type species of Prospira, P. typa Maxwell, 1954 (see also Maxwell, 1961), essentially by the dissymmetry of its flanks and its smooth sulcus. The differences between the new species and P. struniana (Gosselet, 1879) are the following: general shape (subpentagonal in struniana vs. more transverse in pseudostruniana), less curved beak not overhanging the ventral interarea, ventral interarea higher and less concave, sulcus-bounding costae simple (not divided), lateral costae less numerous (10-12 vs. $15-20$ in struniana), delthyrial plate hardly developed. P. pseudostruniana is distinguished from P. lapparenti Brice, 1999 by its clearly larger size, its not fusiform outline, a small number of lateral costae (10-12 vs. 13-15 in lapparenti), the absence of median sulcal costae, the dissymmetry of the flanks and a less developed delthyrial plate. P. pseudostruniana differs from $P$. incerta (Thomas, 1970) by its dissymmetric outline, its lower number of lateral costae, a less curved ventral beak, its dental plates subparallel, the absence of ventral myophragm, its ctenophoridium with less lamellae and its crural bases which are not parallel.

Distribution. Until now, Prospira pseudostruniana sp. nov. is known only from the Etrœungt Formation in the Avesnois (Le Parcq and Godin quarries, Avesnelles railway section).

\begin{tabular}{ccccc}
\hline $\begin{array}{c}\text { Section and } \\
\text { sample }\end{array}$ & GFCL & $\begin{array}{c}\text { Shell width } \\
(\mathrm{mm})\end{array}$ & $\begin{array}{c}\text { Shell length } \\
(\mathrm{mm})\end{array}$ & $\begin{array}{c}\text { Width/ } \\
\text { Length }\end{array}$ \\
\hline AV-EP 42.1 & 2211 & 15.6 & 9.1 & 1.71 \\
AV-ET.1 & 2212 & $19.5 ?$ & 13.7 & $1.42 ?$ \\
AV-EJ 9 & 2213 & 11.4 & 4.3 & 1.56 \\
AV-BO 55 & 2241 & $19 ?$ & 10.2 & $1.86 ?$ \\
AV-BO 143 & 2215 & $23 ?$ & 12 & $1.9 ?$ \\
AV-BO 194 & 2216 & 31.4 & 16 & 1.96 \\
\hline
\end{tabular}

Table 1. Measurements of selected specimens of Prospira pseudostruniana sp. nov.

\section{Famennian brachiopod faunas from southern Belgium: a brief review}

From the brachiopod viewpoint, the Upper Frasnianuppermost Famennian interval is marked by several extinctions and recoveries that were partly studied in southern Belgium. The end Frasnian biological crisis was marked by the disappearance of two emblematic orders on a worldwide scale, namely the atrypides and the pentamerides (e.g. Copper, 2002), and was followed by a relatively rapid postextinction recovery at the base of the Famennian among the athyridides, spiriferides and rhynchonellides, which is well-documented in southern Belgium (e.g. Sartenaer, 1956, 1968, 1972; Mottequin, 2008a, b, c; Mottequin \& Poty, 2016). Brachiopods are particularly abundant in the argillaceous environments of the lower part of the lower Famennian; athyridides (Cleiothyridininae), spiriferides (Cyrtospiriferidae) and rhynchonellides (Leiorhynchidae, Pugnacidae, Trigonirhynchiidae) dominated the rest of the brachiopod faunas including orthides, orthotetides, and productides. During the lower Famennian, besides the fact that the general size of the athyridides, productidines, spiriferides regularly increased (this is not true for the rhynchonellides) probably due to the progressive amelioration of the environmental conditions. The Cyrtiopsinae progressively supplanted the Cyrtospiriferinae (Sartenaer, 1957). Brachiopods from the essentially silty to sandy deposits of middle and upper Famennian age (see Thorez et al. 2006 for more details) still remain less known - some lists were published by Maillieux (1941a, 1941b) - as is the case for those in the more calcareous Souverain-Pré Formation and its Baelen Member. Dreesen et al. $(2013,2015)$ reported rare productidines and spire-bearers (athyridides, spiriferides) in the latter.

The uppermost Famennian succession (see sequential interpretation in Hance et al., 2001) is markedly different from the upper Famennian formations, notably with the occurrence of limestones and that of the first post-Upper Frasnian development of stromatoporoid boundstones within the Comblain-au-Pont and Dolhain formations (e.g. Conil et al., 1964; Aretz \& Chevalier, 2007). As stressed by Poty (1999) for the Strunian rugose corals, the re-establishment of more marine, silty to carbonate environments in southern Belgium, after siliciclastic-dominated nearshore conditions, interpreted as due to sea-level rise probably linked with climatic warming (Streel et al., 2000), favored development of new brachiopod faunas at a global scale (e.g. Simakov, 1990; Mottequin et al., 2014). As already reported above, Demanet (1958) provided faunal lists for the uppermost Famennian succession developed in southern Belgium on the basis of the collections of the Royal Belgian Institute of Natural Sciences; they have partly been complemented and/or revised by Conil et al. (1986) and Legrand-Blain (1991, 1995). Besides Sphenospira julii (Dehée, 1929) and Prospira struniana (Gosselet, 1879) (see above), 
spiriferides also include some smooth and tiny shells that may be representatives of the Ambocoelioidea and which come from the top of the Etrœungt Formation in Anseremme and Gendron. Further material is also necessary in order to discuss the cyrtospiriferides. Five orthotetide species were reported by Demanet (1958) in the uppermost Famennian succession of the southern margin of the Dinant Synclinorium but, after examination of the poorly preserved material housed at the Institut royal des Sciences naturelles de Belgique, this number is most probably overestimated. Orthides are represented by few dissociated valves of Aulacella at the top of the Etrœungt Formation in the Anseremme (beds 148, 152) and GendronCelles sections (bed 38) (see also Conil et al., 1986).

\section{Perspectives}

The revision of the brachiopod faunas which developed in the mixed siliciclastic-carbonate environments prevailing during the uppermost Famennian in the Franco-Belgian Basin is far from complete. This is notably the case for the brachiopods of the uppermost Famennian-Tournaisian Avesnelles Formation in which Legrand-Blain (1995) reported the presence of an abundant brachiopod fauna dominated by the productidines. This contribution represents a new step in the revision of the brachiopods described by Dehée (1929). However, the poor preservation of most of the brachiopods from north-western France and southern Belgium generally precludes detailed systematic studies crucial for assessing the brachiopod diversity prior to the Hangenberg Crisis. New field work will have to be undertaken to gather additional material from southern Belgium where sections are more numerous than in the Avesnois, i.e. the historical type area of the 'Strunian' Substage.

\section{Acknowledgments}

The authors are indebted to Marie Legrand-Blain (Bordeaux) and John Talent (Macquarie University) for critical reading of the manuscript. Grateful thanks are due to Thierry Oudoire (Musée d'Histoire naturelle de Lille) and Valentin Fischer (Université de Liège) for lending specimens and to Julien Cillis and Eric Simon (both at the Institut royal des Sciences naturelles de Belgique) for the SEM pictures. BM also acknowledges Edouard Poty (Université de Liège) for comments on a preliminary version of the manuscript, and Julien Denayer (Université de Liège) and Cyrille Prestianni (Institut royal des Sciences naturelles de Belgique) for their help in the field. This paper is a contribution to the International Geoscience Programme (IGCP) Project 596 - Climate change and biodiversity patterns in the Mid Palaeozoic.

\section{References}

Allan, R.S., 1947. A revision of the brachiopods of the Lower Devonian strata of Reefton, New Zealand. Journal of Paleontology, 21, 436-452.

Aretz, M. \& Chevalier, E., 2007. After the collapse of stromatoporoidcoral reefs - the Famennian and Dinantian reefs of Belgium: much more than Waulsortian mounds. In Álvaro, J.J., Aretz, M., Boulvain, F., Munnecke, A., Vachard, D. \& Vennin, E. (eds), Palaeozoic reefs and bioaccumulations: climatic and evolutionary controls. Geological Society, London, Special Publication, 275, $163-188$.

Austin, R., Conil, R., Rhodes, F. \& Streel, M., 1970. Conodontes, spores et foraminifères du Tournaisien inférieur dans la vallée du Hoyoux. Annales de la Société géologique de Belgique, 93, 305315.

Béclard, F., 1887. Les fossiles coblenziens de Saint-Michel. Bulletin de la Société belge de Géologie, de Paléontologie et d'Hydrologie, Mémoires, 1, 60-96.

Belanger, I., Delaby, S., Delcambre, B., Ghysel, P., Hennebert, M., Laloux, M., Marion, J.-M., Mottequin, B. \& Pingot, J.-L., 2012. Redéfinition des unités structurales du front varisque utilisées dans le cadre de la nouvelle Carte géologique de Wallonie (Belgique). Geologica Belgica, 15, 169-175.

Béthune, P., de, 1954. Carte géologique de Belgique (échelle 1/500.000). Atlas de Belgique, planche 8. Académie royale de Belgique, Bruxelles.
Brice, D., 1999. New data on systematics of some Famennian spiriferid brachiopods from Afghanistan and Iran. Senckenbergiana lethaea, 79, 281-295.

Brice, D., Mottequin, B. \& Loones, C., 2008. Découverte de nouveaux brachiopodes dans le Givétien (Dévonien) du Boulonnais (N. France). Annales de la Société géologique du Nord, $2^{\text {ème }}$ série, 15, $1-14$.

Brice, D., Nicollin, J.-P. \& Mottequin, B., 2013. Diversity of strophomenid, orthotetid and orthid brachiopods in the uppermost Famennian ('Strunian'; Upper Devonian) of the Avesnois (northern France). Annales de la Société géologique du Nord, $2^{\text {ème }}$ série, 20, 53-63.

Brown, T., 1845. Illustrations of the fossil conchology of Great Britain and Ireland, with descriptions and localities of all the species, parts 24-28. Maclachlan and Stewart, Smith, Elder, Edinburgh \& London, 117-136.

Brunton, C.H.C., 1984. Silicified brachiopods from the Viséan of County Fermanagh, Ireland (III). Rhynchonellids, spiriferids and terebratulids. Bulletin of the British Museum (Natural History), Geology, 38, 27-130.

Bublichenko, N.L. \& Nikitina, L.G., 1955. Tarkhanskiy razrez (iogo-zapadnyi Altay) [Tarkhan section (southwest Altay)]. Trudy Altayskogo gorno-metallurgitcheskogo nauchnoissledovatel'skogo instituta N Kaz. SSR, 2. [In Russian].

Buckman, S.S., 1906. Brachiopod nomenclature. Annals and Magazine of Natural History, 18, 321-327.

Bultynck, P. \& Dejonghe, L., 2002. Devonian lithostratigraphic units (Belgium). Geologica Belgica, 4, 39-69.

Carter, J.L., 1974. New genera of spiriferid and brachythyridid brachiopods. Journal of Paleontology, 48, 674-696.

Conil, R., 1961. Les gîtes à stromatopores du Strunien de la Belgique. Mémoires de l'Institut géologique de l'Université de Louvain, 22, 335-369.

Conil, R., Dreesen, R., Lentz, M.-A., Lys, M. \& Plodowski, G., 1986. The Devono-Carboniferous transition in the Franco-Belgian Basin with reference to Foraminifera and Brachiopods. Annales de la Société géologique de Belgique, 109, 19-26.

Conil, R. \& Lys, M., 1968. Aperçu sur les associations de Foraminifères endothyroïdes du Dinantien de la Belgique. Annales de la Société géologique de Belgique, 91, 491-557.

Conil, R. \& Lys, M., 1970. Données nouvelles sur les foraminifères des couches de passage du Famennien au Tournaisien dans l'Avesnois. Congrès et colloques de l'Université de Liège, 55, 241265.

Conil, R., Lys, M. \& Paproth, E., 1964. Localités et coupes types pour l'étude du Tournaisien inférieur (révision des limites sous l'aspect micropaléontologique). Académie Royale de Belgique, Classe des Sciences, Mémoires in-4 $4^{\circ}, 2^{\text {ème }}$ série, 15/4, 1-87.

Cooper, G.A., 1954. Unusual Devonian brachiopods. Journal of Paleontology, 28, 325-332.

Cooper, G.A. \& Dutro, J.T. Jr., 1982. Devonian brachiopods of New Mexico. Bulletins of American Paleontology, 82-83, 1-215.

Copper, P., 1986. Frasnian/Famennian mass extinctions and coldwater oceans. Geology, 14, 835-839.

Copper, P., 2002. Reef development at the Frasnian/Famennian mass extinction boundary. Palaeogeography, Palaeoclimatology, Palaeoecology, 181, 27-65.

Dehée, R., 1929. Description de la faune d'Etrœungt - Faune de passage du Dévonien au Carbonifère. Mémoires de la Société géologique de France, nouvelle série, 5, 1-62.

Demanet, F., 1958. Contribution à l'étude du Dinantien de la Belgique. Mémoires de l'Institut royal des Sciences naturelles de Belgique, 141, 1-152.

Denayer, J., Poty, E., Marion, J.-M. \& Mottequin, B., 2012. Lower and Middle Famennian (Upper Devonian) rugose corals from southern Belgium and northern France. In Denayer, J., Aretz, M. \& Poty, E. (eds). Proceedings of the 11th International Symposium on Fossil Cnidaria and Porifera, Liège, Belgium, 2011. Geologica Belgica, 15, 273-283.

Denayer, J., Prestianni, C., Sautois, M., Poty, E. \& Mottequin, B., 2015. Devonian-Carboniferous Boundary and the Lower Carboniferous succession in the type area. In Denayer, J., Mottequin, B. \& Prestianni, C. (eds), IGCP596-SDS Symposium, Climate change and Biodiversity patterns in the Mid-Palaeozoic, Field Guidebooks. Strata, Communications, 17, 59-81.

Dreesen, R., Dusar, M. \& Groessens, E., 1976. Biostratigraphy of the Yves-Gomezée road section (Uppermost Famennian).Service géologique de Belgique, Professional Paper, 1976/6, 1-20.

Dreesen, R., Marion, J.-M. \& Mottequin, B., 2013. The Red Marble of Baelen, a particular historical building stone with global geological importance and local use. Geologica Belgica, 16, 179190 . 
Dreesen, R., Vachard, D., Marion, J.-M. \& Mottequin, B., 2015. The Red Marble of Baelen, an exceptional mid-Famennian mud mound complex in a carbonate ramp setting from Eastern Belgium. In Mottequin, B., Denayer, J., Königshof, P., Prestianni, C. \& Olive, S. (eds), IGCP596 - SDS Symposium, Climate change and Biodiversity patterns in the Mid-Palaeozoic, Abstracts. Strata, Communications, 16, 46-47.

Goldring, R., 1957. The last toothed Productellinae in Europe. Paläontologische Zeitschrift, 31, 207-228.

Gosselet, J., 1857. Note sur les Terrains dévoniens de l'Ardenne et du Hainaut. Bulletin de la Société Géologique de France, $2^{\text {ème }}$ série, 14, 364-374

Gosselet, J., 1860. Mémoire sur les terrains primaires de la Belgique, des environs d'Avesnes et du Boulonnais. Imprimerie L. Martinet, Paris, $164 \mathrm{p}$

Gosselet, J., 1879. Nouveaux documents pour l'étude du Famennien - Tranchées de chemin de fer entre Féron et Sémeries. Schistes de Sains. Annales de la Société géologique du Nord, 6, 389-399.

Gosselet, J., 1880. Esquisse géologique du Nord de la France et des Contrées voisines. $1^{\text {er }}$ fascicule : Terrains primaires (texte). Imprimerie Six-Horemans, Lille, 167 p.

Gosselet, J., 1887. Note sur quelques rhynchonelles du terrain dévonique supérieur. Annales de la Société géologique du Nord, $14,188-221$.

Gosselet, J., 1888. L'Ardenne. Ministère des travaux publics, Mémoires pour Servir à l'Explication de la Carte géologique détaillée de la France. Baudry \& Cie, Paris, 889 p.

Halamski, A.T. \& Baliński, A., 2009. Latest Famennian brachiopods from Kowala, Holy Cross Mountains, Poland. Acta Palaeontologica Polonica, 54, 289-306.

Hall, J. \& Clarke, J.M., 1893. An Introduction to the Study of the Genera of Palaeozoic Brachiopoda. Palaeontology of New York, vol. 8, Part 2. Charles van Benthuysen \& Sons, Albany, 317 p.

Hance, L. \& Poty, E., 2006. Hastarian. Geologica Belgica, 9, 111-116.

Hance, L., Poty, E. \& Devuyst, F.-X., 2001. Stratigraphie séquentielle du Dinantien type (Belgique) et corrélation avec le Nord de la France (Boulonnais, Avesnois). Bulletin de la Société Géologique de France, 172, 411-426.

Hébert, M., 1855. Quelques renseignements nouveaux sur la constitution géologique de l'Ardenne française. Bulletin de la Société géologique de France, $2^{\text {ème }}$ série, 12, 1165-1186.

Hubert, B.L.M., Devleeschouwer, X., Mistiaen, B., Brice, D., Nicollin, J.-P., Cambier, G., Vallet, F., Poty, E. \& Mottequin, B., 2013. Macrofauna, rock magnetism and sedimentology in the Etrœungt Limestone ('Strunian', Uppermost Famennian) at Avesnelles (northern France). In Whalen, M., Osadetz, K., Richards, B. et al. (eds), IGCP 580-596 Geophysical and geochemical techniques: A window on the Palaeozoic World, Programme with abstracts. Geological Survey of Canada and ERCB Core Research Center, Calgary, 36-37.

International Commission on Zoological Nomenclature, 1999. International Code of Zoological Nomenclature, $4^{\text {th }}$ ed. International Trust for Zoological Nomenclature, London, $338 \mathrm{p}$.

Ivanova, E.A., 1960. Otryad Spiriferida [Order Spiriferida]. In Sarycheva T.G. (asst. ed.), Mshanki, Brakhiopody [Bryozoa, Brachiopoda] in Orlov, Iu. A. (ed.), Osnovi Paleontologii [Fundamentals of Paleontology], vol. 7. Izdatel'stvo Akademii Nauk SSSR, Moscow, 264-280. [In Russian].

Johnson, J.G. \& Hou H., 2006. Delthyridoidea. In Kaesler, R.L. (ed.), Treatise on Invertebrate Paleontology, Part H, Brachiopoda, 5 (revised). Boulder and Lawrence, Geological Society of America and University of Kansas, 1825-1847.

Kaiser, S.I., Aretz, M. \& Becker, R.T., 2016 (in press). The global Hangenberg Crisis (Devonian-Carboniferous transition): review of a first-order mass extinction. In Becker, R.T., Königshof, P. $\&$ Brett, C.E. (eds), Devonian climate, sea level and evolutionary events. Geological Society, London, Special Publications, 423 , http://doi.org/10.1144/SP423.9

Kaiser, S.I., Becker, R.T., Steuber, T. \& Aboussalam, S.Z., 2011. Climate-controlled mass extinctions, facies, and sea-level changes around the Devonian-Carboniferous boundary in the eastern Anti-Atlas (SE Morocco). Palaeogeography, Palaeoclimatology, Palaeoecology, 310, 340-364

King, W., 1846. Remarks on certain genera belonging to the class Palliobranchiata. Annals and Magazine of Natural History, 18, 26-42, 83-94.

Koninck, L.-G. de, 1887. Faune du calcaire carbonifère de la Belgique. Sixième partie. Brachiopodes. Annales du Musée d'Histoire naturelle de Belgique, 14, 1-154.
Krestovnikov, V.N. \& Karpyshev, V.S., 1948. Fauna i stratigrafiia sloev Etroeungt reki Zigan (Iuzhnyi Ural) [Fauna and stratigraphy of the Etroeungian beds of the Zigan river (southern Ural mountains)]. Trudy Geologicheskii Institut Akademii Nauk SSSR (Geologii), 66/21, 29-66. [In Russian].

Le Maître, D., 1932. Les Stromatoporoïdes de la zone d'Etrœungt (Note préliminaire). Annales de la Société géologique du Nord, 51, 207-212.

Legrand-Blain, M., 1991. Les Brachiopodes Productacés Spinocarinifera nigra (Gosselet, 1888) et formes voisines dans le Dévono-Dinantien du Nord de la France et de la Belgique. Annales de la Société géologique du Nord, $2^{\text {ème }}$ série, 1, 29-52.

Legrand-Blain, M., 1995. Relations entre les domaines d'Europe occidentale, d'Europe méridionale (Montagne Noire) et d'Afrique du Nord à la limite Dévonien-Carbonifère : les données des brachiopodes. Bulletin de la Société belge de Géologie, 103, 77-97.

M'Coy, F., 1841. A catalogue of the Museum of the Geological Society of Dublin. Hodges and Smith, Dublin, 28 p.

M'Coy, F., 1844. A synopsis of the characters of the Carboniferous Limestone fossils of Ireland. Williams and Norgate, London, 207

M'Coy, F., 1855. Systematic descriptions of the British Palaeozoic fossils in the Geological Museum of the University of Cambridge, vol. 3. J.W. Parker, London, 407-661.

Maillieux, E., 1941a. Répartition des Spiriferifae et des Spiriferinidae dans le Dévonien de l'Ardenne. Bulletin du Musée royal d'Histoire naturelle de Belgique, 17/13, 1-6.

Maillieux, E., 1941b. Répartition des brachiopodes dans le Dévonien de l'Ardenne. Bulletin du Musée royal d'Histoire naturelle de Belgique, 17/30, 1-14.

Martin, W., 1809. Petrificata Derbiensia; or Figures and descriptions of petrifactions collected in Derbyshire. D. Lyon, Wigan, 28 p.

Martynova, M.V., 1961. Stratigrafiia i brakhiopody Famenskogo iarusa zapadnoi chasti tsentralnogo Kazakhstana [Stratigraphy and brachiopods of the Famennian stage in west central Kazakhstan]. Materialy po Geologii Tsentral'nogo Kazakhstana, 2, 1-211. [In Russian].

Maxwell, W.G.H., 1954. Upper Palaeozoic formations in the Mount Morgan district faunas. University of Queensland Papers (Geology), 4/5, 1-69.

Maxwell, W.G.H., 1961. Lower Carboniferous brachiopod faunas from Old Cannindah, Queensland. Journal of Paleontology, 35, $82-103$.

Maziane-Serraj, N., Hartkopf-Fröder, C., Streel, M. \& Thorez, J., 2007. Palynomorph distribution and bathymetry in the Chanxhe section (eastern Belgium), reference for the neritic late to latest Famennian transition (Late Devonian). Geologica Belgica, 10, 170-175.

Milhau, B., Mistiaen, B., Brice, D., Degardin, J.-M., Derycke, C., Hou, H., Rohart, J.-C., Vachard, D. \& Wu, X., 1997. Comparative faunal content of Strunian (Devonian) between Etaoucun (Guilin, Guangwi, South China) and the stratotype area (Etrœungt, Avesnois, North of France). In Jin, Y.-G. \& Dineley, D. (eds), Palaeontology and historical geology. Proceedings of the $30^{\text {th }}$ International Geological Congress, 12, 79-94.

Minato, M., 1951. On the Lower Carboniferous fossils of the Kitakami Massif, northeast Honshu, Japan. Journal of the Faculty of Science, Hokkaido University (series 4, Geology and Mineralogy), 7, 355-382.

Mistiaen, B., 1997. Découverte du genre Amphipora Schulz, 1883 , dans le Famennien terminal «Strunien», de la carrière du Parcq, à Etrœungt, stratotype du Calcaire d'Etrœungt et ailleurs en Avesnois (Nord de la France). Comptes rendus de l'Académie des Sciences de Paris, Série IIa, 324, 655-662.

Mistiaen, B., Brice, D., Devleeschouwer, X., Hubert, B.L.M., Khatir, A., Mottequin, B., Nicollin, J.-P. \& Poty, E., 2013. Le « Calcaire d'Etrœungt » dans les coupes historiques d'Etrœungt et d'Avesnelles (Avesnois, Nord, France). Annales de la Société géologique du Nord, $2^{\text {ème }}$ série, 20, 43-51.

Mortelmans, G., 1969. L'étage Tournaisien dans sa localité-type. Compte rendu du Sixième Congrès International de Stratigraphie et de Géologie du Carbonifère, Sheffield 1967, volume 1, 19-44.

Mottequin, B., 2008a. Late middle Frasnian to early Famennian (Late Devonian) strophomenid, orthotetid and athyridid brachiopods from southern Belgium. Journal of Paleontology, 82, 1052-1073.

Mottequin, B., 2008b. New observations on Upper Devonian brachiopods from the Namur-Dinant Basin (Belgium). Geodiversitas, 30, 455-537.

Mottequin, B., 2008c. Late Middle to Late Frasnian Atrypida, Pentamerida, and Terebratulida (Brachiopoda) from southern Belgium. Geobios, 41, 493-513. 
Mottequin, B., 2010. Mississippian (Tournaisian) brachiopods from the Hook Head Formation, County Wexford (south-east Ireland). Special Papers in Palaeontology, 84, 243-285.

Mottequin, B., Brice, D. \& Legrand-Blain, M., 2014. Biostratigraphic significance of brachiopods near the Devonian-Carboniferous boundary. Geological Magazine, 151, 216-228.

Mottequin, B. \& Poty, E., 2014. The uppermost Famennian Hangenberg Event in the Namur-Dinant Basin (southern Belgium). Berichte des Institutes für Erdwissenschaften, KarlFranzens-Universität Graz, 19, 36-37.

Mottequin, B. \& Poty, E., 2016 (in press). Kellwasser horizons, sealevel changes and brachiopod-coral crises during the late Frasnian in the Namur-Dinant Basin (southern Belgium): a synopsis. In Becker, R.T., Königshof, P. \& Brett, C.E. (eds), Devonian climate, sea level and evolutionary events. Geological Society, London, Special Publications, 423, doi.org/10.1144/SP423.6.

Nicollin, J.-P., 2004. Revision and stratigraphical importance of "Spirifer julii" Dehée, 1929, a typical spiriferid species from Uppermost Devonian. The Palaeontology Newsletter, 57, 172.

Nicollin, J.-P., 2008. Etude comparée de deux groupes d'organismes benthiques fossiles: les foraminifères du Lias et les brachiopodes du Dévonien et de la base du Carbonifère. Unpublished H.D.R. thesis, Université des Sciences et Techniques de Lille, 127 p.

North, F.J., 1920. On Syringothyris Winchell and certain Carboniferous Brachiopoda referred to Spiriferina d'Orbigny. Quarterly Journal of the Geological Society of London, 76, 162-227.

Orbigny, A., d', 1849. Prodrome de paléontologie stratigraphique universelle des animaux mollusques et rayonnés, faisant suite au cours élémentaire de paléontologie et de géologie stratigraphiques. Volume 1. Victor Masson, Paris, 394 p.

Paeckelmann, W., 1931. Die Brachiopoden des deutschen Unterkarbons. 2. Teil: Die Productinae und Productus-ähnlichen Chonetinae. Abhandlungen der Preussischen Geologischen Landesanstalt (Neue Folge), 136, 1-441.

Paeckelmann, W., 1942. Beiträge zur Kenntnis devonischer Spiriferen. Abhandlungen des Reichsamts für Bodenforschung (Neue Folge), 197, 1-188.

Phillips, J., 1836. Illustrations of the geology of Yorkshire, Part 2. The mountain limestone district. John Murray, London, $253 \mathrm{p}$.

Phillips, J., 1841. Figures and descriptions of the Palaeozoic fossils of Cornwall, Devon, and West Somerset. Longman, Brown, Green and Longmans, London, $231 \mathrm{p}$.

Poty, E., 1999. Famennian and Tournaisian recoveries of shallow water Rugosa following late Frasnian and late Strunian major crises, southern Belgium and surrounding areas, Hunan (South China) and the Omolon region (NE Siberia). Palaeogeography, Palaeoclimatology, Palaeoecology, 154, 11-26.

Poty, E., Aretz, M. \& Denayer, J., 2011. Field trip 3. Uppermost Devonian and Lower Carboniferous of Southern Belgium. In Aretz, M. \& Poty, E. (eds), $11^{\text {th }}$ Symposium on Fossil Cnidaria and Porifera, Liège, Belgium, August 19-29, 2011, Field Guides. Kölner Forum für Geologie und Paläontologie, 20, 99-150.

Poty, E., Aretz, M. \& Hance, L., 2014. Belgian substages as a basis for an international chronostratigraphic division of the Tournaisian and Viséan. Geological Magazine, 151, 229-243.

Poty, E., Devuyst, F.-X. \& Hance, L., 2006. Upper Devonian and Mississippian foraminiferal and rugose coral zonations of Belgium and Northern France: a tool for Eurasian correlations. Geological Magazine, 143, 829-857.

Richter, R. \& Richter, E., 1933. Die letzten Phacopidae. Bulletin du Musée royal d'Histoire naturelle de Belgique, 9/21, 1-19.

Rome, D.R., 1936. Note sur la microstructure de l'appareil tégumentaire de Phacops (Ph.) accipitrinus maretiolensis R. \& E. Richter. Bulletin du Musée royal d'Histoire naturelle de Belgique, 12/31, 1-7.

Sartenaer, P., 1956. Signification et importance du genre Cyrtiopsis dans les dépôts famenniens inférieurs. Deuxième note : Cyrtiopsi senceliae, nov. sp. Bulletin de l'Institut royal des Sciences naturelles de Belgique, 32/40, 1-12.

Sartenaer, P., 1957. Esquisse d'une division nouvelle des dépôts du Famennien inférieur du Bassin de Dinant. Bulletin de la Société belge de Géologie, de Paléontologie et d'Hydrologie, 65, 421-446.

Sartenaer, P., 1968. De l'importance stratigraphique des rhynchonelles famenniennes situées sous la Zone à Ptychomaletoechia omaliusi (Gosselet, J., 1877). Cinquième note: Paromoeopygma n. gen. Bulletin de l'Institut royal des Sciences naturelles de Belgique, 44/42, 1-26.

Sartenaer, P., 1970. Nouveaux genres rhynchonellides (brachiopodes) du Paléozoïque. Bulletin de l'Institut royal des Sciences naturelles de Belgique, 46/32, 1-32.

Sartenaer, P., 1972. De l'importance stratigraphique des rhynchonellides famenniens situés au-dessus de la Zone à Ptychomaletoechia dumonti (Gosselet, J., 1877). Première note : Cavatisinurostrum n. gen. Bulletin de l'Institut royal des Sciences naturelles de Belgique, 48/2, 1-22.
Sartenaer, P. \& Plodowski, G., 1975. Importance stratigraphique et répartition géographique du genre rhynchonellide Araratella n. gen. du Famennien supérieur. Bulletin de l'Institut royal des Sciences naturelles de Belgique, Sciences de la Terre, 51/8, 1-34.

Sartenaer, P. \& Plodowski, G., 2003. Reassessment of the Strunian genus Araratella Abramian, Plodowski and Sartenaer, 1975 in the northern Gondwanaland (Rhynchonellida, Brachiopoda). Courier Forschungsinstitut Senckenberg, 242, 329-348.

Sarycheva, T.G., Sokolskaya, A.N., Beznosova, G.A. \& Maksimova, S.V., 1963. Brakhiopody i paleogeografiia Karbona Kuznetskoi kotloviny [Carboniferous brachiopods and palaeogeography of the Kuznetsk Basin]. Akademiia Nauk SSSR, Trudy Paleontologicheskogo Instituta 95, 1-547. [In Russian].

Schemm-Gregory, M., 2008. A new species of Filispirifer (Brachiopoda: Delthyridoidea) from the Dra Valley, Morocco (Lower Devonian). Zootaxa, 1739, 53-68

Schuchert, C. \& LeVene, C.M., 1929. Brachiopoda (Generum et genotyporum index et bibliographia). In Pompeckj, J.F. (ed.), Fossilium Catalogus, I: Animalia, part 42. W. Junk. Berlin, 1-140.

Simakov, K.V., 1990. Major evolutionary events among spiriferids at the Devonian-Carboniferous boundary. In Kauffman, E.G. \& Walliser, O.H. (eds), Extinction Events in Earth History. Springer, Berlin, Lecture Notes in Earth Sciences, 30, 189-198.

Sokolskaya, A.N., 1948. Evoliutsiia roda Productella Hall smezhnykh s nim form v Paleozoe Podmoskovnoi kotloviny [Evolution of the genus Productella Hall and related forms in the Palaeozoic of the Moscow region]. Akademiia Nauk SSSR, Trudy Paleontologicheskogo Instituta, 14/3, 1-170. [In Russian].

Sokolskaya, A.N., 1950. Chonetidae Russkoy Platformy [Chonetidae of the Russian Platform]. Akademiia Nauk SSSR, Trudy Paleontologicheskogo Instituta, 27, 1-108. [In Russian].

Sowerby, J. de C., 1840. Explanation of the plates and woodcuts. In Sedgwick, A. \& Murchison, R.I., On the physical structure of Devonshire, and on the subdivisions and geological relations of its older stratified deposits. Transactions of the Geological Society of London, $2^{\text {nd }}$ series, 5, 633-703.

Streel, M., Brice, D. \& Mistiaen, B., 2006. Strunian. Geologica Belgica, 9, 105-109.

Streel, M., Caputo, M.V., Loboziak, S. \& Melo, J.H.G., 2000. Late Frasnian-Famennian climates based on palynomorph analyses and the question of the Late Devonian glaciations. Earth-Science Reviews, 52, 121-173.

Thomas, G.A., 1971. Carboniferous and early Permian brachiopods from western and northern Australia. Bureau of Mineral Resources, Geology and Geophysics bulletin, 56, 1-285.

Thorez, J., Bless, M., Bouckaert, J., Conil, R., Dreesen, R., Groessens, E. \& Streel, M., 1974. Excursion D. In Bouckaert, J. \& Streel, M. (eds), Guidebook of the International Symposium on Belgian Micropaleontological limits, from Emsian to Visean, September 1-10, Namur 1974. Service géologique de Belgique, Bruxelles, $1-40$

Thorez, J., Dreesen, R. \& Streel, M., 2006. Famennian. Geologica Belgica, 9, 27-45

Tolokonnikova, Z., Ernst, A., Poty, E. \& Mottequin, B., 2015. Middle and uppermost Famennian (Upper Devonian) bryozoans from southern Belgium. Bulletin of Geosciences, 90, 33-49.

Van Steenwinkel, M., 1990. Sequence stratigraphy from 'spot' outcrops: example from a carbonate-dominated setting. Devonian-Carboniferous transition, Dinant Synclinorium (Belgium). Sedimentary Geology, 69, 259-280.

Vandercammen, A., 1956. Révision de Spinocyrtia struniana (J. Gosselet 1879) (Spiriferidae). Bulletin de l'Institut royal des Sciences naturelles de Belgique, 32/59, 1-10.

Vandercammen, A., 1963. Spiriferidae du Dévonien de la Belgique. Mémoires de l'Institut royal des Sciences naturelles de Belgique, 150, 1-179.

Vaughan, A., 1915. Correlation of Dinantian and Avonian. Quarterly Journal of the Geological Society of London, 71, 1-49.

Waagen, W.H., 1883. Salt Range Fossils. I. Productus-Limestone Fossils. Geological Survey of India, Memoirs, Palaeontologia Indica, $13^{\text {rd }}$ series, 4/2, 391-546.

White, C.A., 1860. Observations upon the geology and paleontology of Burlington, Iowa and its vicinity. Boston Journal of Natural History, 7/2, 209-235.

Manuscript received 27.11.2015, accepted in revised form 11.03.2016, available on line 28.06.2016. 